\title{
Episodic eolian sand deposition in the past 4000 years in Cape Cod National Seashore, Massachusetts, USA in response to possible hurricane/storm and anthropogenic disturbances
}

\author{
Steven L. Forman* \\ Geoluminescence Dating Research Laboratory, Department of Geology, Baylor University, Waco, TX, USA
}

\section{Edited by:}

Gary E. Stinchcomb, Murray State

University, USA

Reviewed by:

Donald Michael Thieme, Valdosta

State University, USA

Edward John Rhodes, University of

California, Los Angeles, USA

*Correspondence:

Steven L. Forman,

Geoluminescence Dating Research

Laboratory, Department of Geology,

Baylor University, One Bear Place

\#97354 Waco, TX 76798-7354, USA

e-mail:steven_forman@baylor.edu
The eolian sand depositional record for a dune field within Cape Cod National Seashore, Massachusetts is posit as a sensitive indicator of environmental disturbances in the late Holocene from a combination of factors such as hurricane/storm and forest fire occurrence, and anthropogenic activity. Stratigraphic and sedimentologic observations, particularly the burial of Spodosol-like soils, and associated ${ }^{14} \mathrm{C}$ and $\mathrm{OSL}$ ages that are concordant indicate at least six eolian depositional events at ca. 3750, 2500, 1800, 960, 430 , and $<250$ years ago. The two oldest events are documented at just one locality and thus, the pervasiveness of this eolian activity is unknown. However, the four younger events are identified in three or more sites and show evidence for dune migration and sand sheet accretion. The timing of eolian deposition, particularly the initiation age, corresponds to documented periods of increased storminess/hurricane activity in the North Atlantic Ocean at ca. 2.0-1.6, and $1.0 \mathrm{ka}$ and also a wetter coastal climate, which suppressed the occurrence of forest fire. Thus, local droughts are not associated with periods of dune movement in this mesic environment. Latest eolian activity on outer Cape Cod commenced in the past 300-500 years and may reflect multiple factors including broad-scale landscape disturbance with European colonization, an increased incidence of forest fires and heightened storminess. Eolian systems of Cape Cod appear to be sensitive to landscape disturbance and prior to European settlement may reflect predominantly hurricane/storm disturbance, despite generally mesic conditions in past $4 \mathrm{ka}$.

Keywords: eolian, dunes, Cape Cod, landscape disturbance, hurricane, Holocene

\section{INTRODUCTION}

Eolian landscapes like actively migrating parabolic dunes on the outer coast of Cape Cod, Massachusetts and within Cape Cod National Seashore (Figure 1) are sensitive indicators of environmental change. Activation of this dune system reflects fundamental sedimentologic controls on sand availability and supply and the persistence of wind speeds that surpass a threshold $(>5 \mathrm{~m} / \mathrm{s})$ for particle entrainment (Fryberger and Dean, 1979; Pye and Tsoar, 1990, pp. 127-145). The availability of sand for eolian transport is often mediated by the type and extent of vegetation cover on dunes, and may be further controlled by moisture availability, edaphic associations (cf. related to soil processes) and landscape disturbance (e.g., Sala et al., 1988; Mangan et al., 2004; Hugenholtz and Wolfe, 2005; Luna et al., 2011). Cape Cod is a mesic (e.g., moist) environment with mean annual precipitation of $106.5 \mathrm{~cm}$ and with mean monthly totals that are relatively consistent between 7 and $11 \mathrm{~cm}$ (Provincetown: 1941-2000; NOAA, 2002). Despite these wet conditions parabolic dunes on the outermost coast of Cape Cod are currently active and have average migration rates between 2.1 and $3.4 \mathrm{~m} /$ year for the 20th and 21 st century (Forman et al., 2008). The avalanche slopes of these actively migrating dunes are burying an adjacent forest of pitch pine and oak; an observation also made by naturalist Henry David Thoreau in 1849 (Thoreau, 2004, p. 160).

The current migration of dunes on Cape Cod is inferred to reflect a legacy of landscape disturbance, specifically forest clear-cutting, grazing and agricultural practices, associated with European settlement starting in the early 17th century and continuing into the 20th century (McCaffrey and Leatherman, 1979; Stilgoe, 1981; Rubertone, 1985; Motzkin et al., 2002; Eberhardt et al., 2003; Forman et al., 2008). Other factors such as storminess, hurricane-force winds (Bosse et al., 2001; Eberhardt et al., 2003) and forest fires (Motzkin et al., 2002; Parshall et al., 2003) may have contributed to historic disturbance of this dune landscape. Numerous geomorphic studies along coasts of the European North Atlantic implicate increased storminess in the Holocene with the reactivation of coastal dune system (e.g., Clarke and Rendell, 2009; Hansom and Hall, 2009). However, uncertainty remains if periods of increased storminess and/or hurricane landfalls for the exposed Cape Cod spit during the Holocene (Mann et al., 2009; Toomey et al., 2013) were of sufficient magnitude to disturb this forest ecosystem and reactivated dunes. Proxy records 


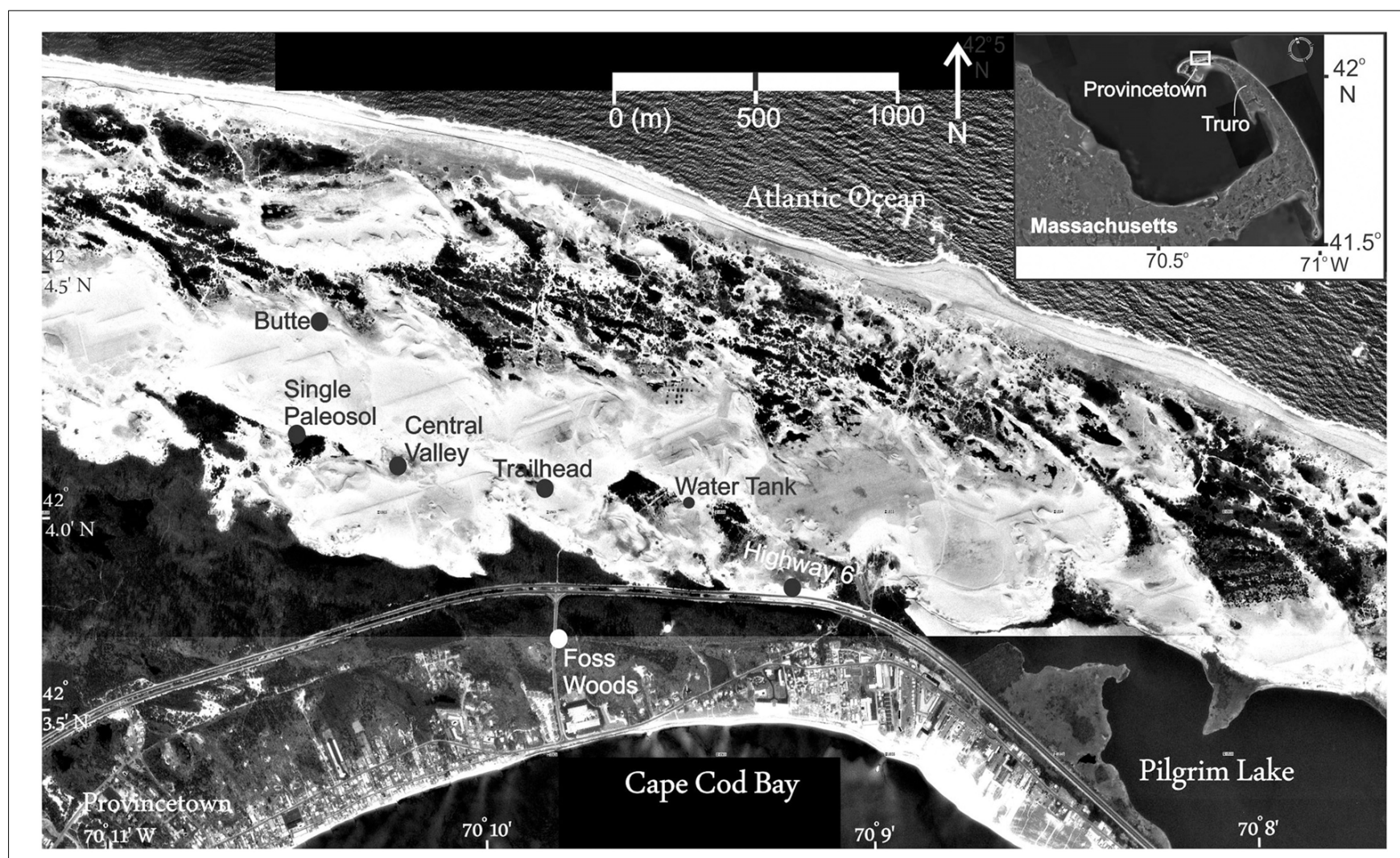

FIGURE 1 | Outer Cape Cod National Seashore showing parabolic dunes and study sites of the informally named Cape Cod dune field (modified from Forman et al., 2008).

of hurricane occurrence from coastal overwash timeseries (e.g., Donnelly et al., 2001; Scileppi and Donnelly, 2007) and from marine sediment cores extracted strategically along the Bahama Bank (Williams, 2013) to reflect wave climate indicate heightened hurricane activity in the North Atlantic Ocean between 4900 and 3600, 2500, and 1000, and 600 and 400 years BP (Mann et al., 2009; Toomey et al., 2013).

Thisstudy presentsstratigraphic, sedimentologic, and pedologic observationsformultipleeolian-sand depositionaleventsinthepast 4000 years for the outer-most area of Cape Cod National Sea Shore, Massachusetts (Figure 1). Chronologic control is provided by radiocarbondating of wood remainsfromburied soils(Abhorizons) and opticallystimulatedluminescence(OSL) dating ofquartzgrains from eolian sands. Thisstudy refines a nascent chronology for eolian deposition presented in Forman et al. (2008). These results bear on the role of anthropogenic and natural (hurricane/storminess) disturbance on activation of eolian systems in mesic coastal areas in the eastern U.S.A., like Cape Cod (Figure 1). This record of eolian sedimentation may provide another metric for paleotempestology along coasts of eastern North America (cf. Liu, 2004) and insights into ecological disturbance with increased storminess (cf. Bosse et al., 2001; Zeng et al., 2009).

\section{GEOMORPHIC CONTEXT}

The most pervasive eolian landforms on outermost Cape Cod are the kilometer-scale parabolic dunes. The orientation these dunes indicates migration from the west to northwest, consistent with the wind drift potential during winter (Figure 2). Eolian transport may dominate during the late fall to early winter with the common exceedance of threshold wind velocities $(>5 \mathrm{~m} / \mathrm{s})$ for eolian entrainment (Forman et al., 2008). Also, a low vegetation cover and a drier moisture status of the dune landscape in late fall and early winter may enhance further eolian transport (cf. Ollerhead et al., 2013). Often the presence of snow and interstitial ice binds eolian particles to surfaces necessitating higher threshold shear velocities for transport (Barchyn and Hugenholtz, 2012; Ollerhead et al., 2013), though the sublimation rate may be an important factor in grain release (Vandijk and Law, 1995). The presence of snow ramparts and interstitial layers mostly composed of snow can enhance eolian accretion and dune movement (Koster and Dijkmans, 1988; Dijkmans and Mucher, 1989; Ruz and Allard, 1995). Lastly, eolian transport is accelerated during hurricane passage with wind speeds of $>50 \mathrm{~m} / \mathrm{s}$. Most storm tracks that impact Cape Cod in the 20th century have a trajectory from the southwest to the northeast, with winds shifting from the northwest and west with westward passage of a cyclonic disturbance (Foster and Boose, 1995, p. 309; Motzkin et al., 2002). Local winds associated with the passage of storms may be topographically funneled by the preexisting tall dune forms.

Inset into these large parabolic forms on outer Cape Cod are smaller blow-out or incipient parabolic dunes, with the lateral 


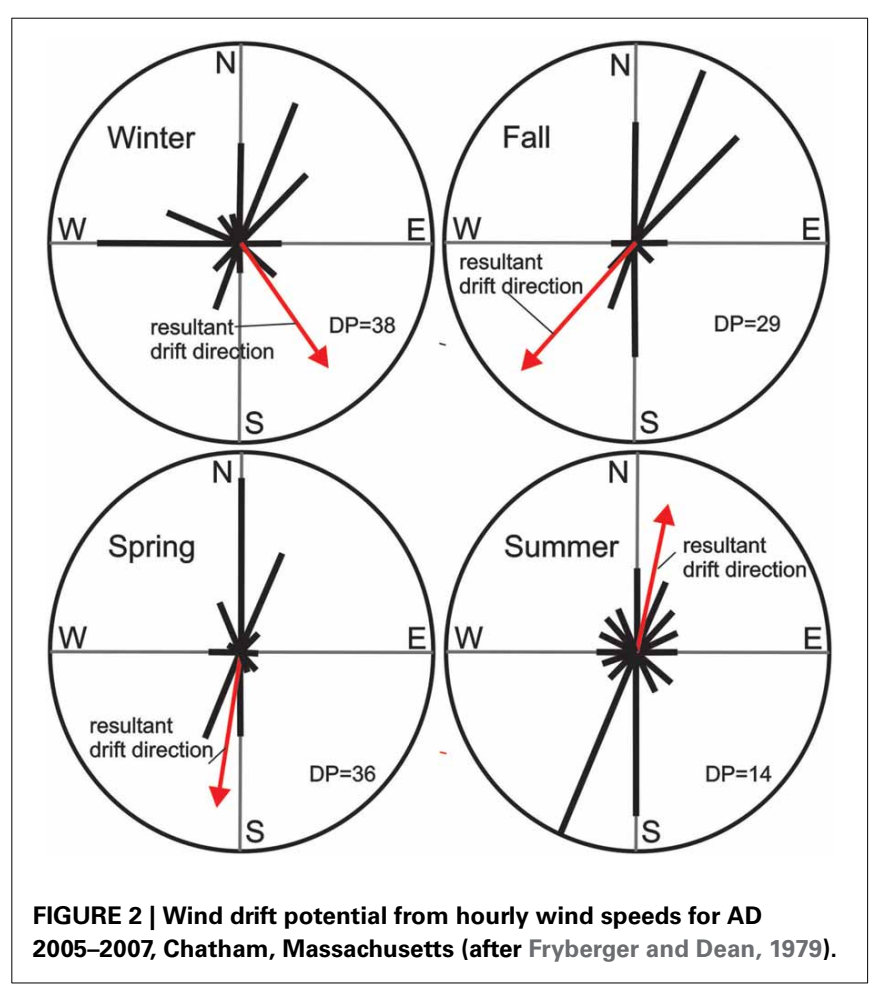

transport of sand limited by the ubiquitous occurrence of the pioneering plant species: American beach grass (Ammophila breviligulata). This common coastal grass thrives where sand accretion rates are 5-40 cm/year (Maun and Lapierre, 1984; Maun, 1998; Maun and Perumal, 1999) and on Cape Cod promotes vertical accretion and horizontal extension of parabolic dunes (Forman et al., 2008). The viability of beach grass is restricted with burial rates $>60 \mathrm{~cm}$ /year of eolian sand (cf. Disraeli, 1984; Maun, 1998), resulting in a net reduction in vegetation cover and less impedance of saltation. The kilometer-scale of the larger parabolic forms may reflect sustained ability of American Beach Grass to trap sand as these dunes developed (Luna et al., 2011).

Dune reactivation is associated with large-scale disturbance of the forest which is dominated by pitch pine (Pinus rigida) and a variety of oak species (e.g., Quercus alba, and Quercus coccinea), but white pine (Pinus strobes), red maple (Acer rubrum), hickory (Carya spp.), and American beech (Fagus grandifolia) are locally common (Motzkin et al., 1999; Cogbill et al., 2002). Cape Cod with its limited topographic relief and dominance of pine forests is particularly susceptible to tree blow-down with Fujita scale winds $>2$ ( $>181 \mathrm{~km} / \mathrm{h}$; cf. Bosse et al., 2001). Tropical storms of hurricane intensity are known to blow down large forest areas along tracks that are $50-100 \mathrm{~km}$ in width and extend for $100 \mathrm{~s}$ of kilometers in New England (Foster et al., 2006, p. 49; Zeng et al., 2009). Specifically, nearly $100 \%$ of pine stands older than 20 years were damaged by a hurricane in 1938 that impacted central New England, whereas hardwood stands were less effected (Foster, 1988). The mound and pit mircotopography associated with wind uprooted trees can dominate landscapes. For example, in New Brunswick up to $50 \%$ of a forest area post-storm was affected with 600 mounds/acre (Foster and Boose, 1995, p. 323) and such processes have been documented in the past ca. 1000 years (Foster et al., 2006, p. 49). The pit and mound topography provides fresh grains for eolian transport and initiates ecological succession with pioneer species occupying the mound (cf. Peterson et al., 1990). The recovery of coastal dune systems post-hurricane is also dependent on the frequency of succeeding storms (e.g., Houser, 2013) and thus, dune movement can be sustained with decadal to centennial periods of heightened hurricane/storm reoccurrence (e.g., Mann et al., 2009; Toomey et al., 2013). Also, ecologic succession to a climax forest post-disturbance can take centuries (Lichter, 2000), though trees $<20$ years old are less susceptible to wind uprooting (Foster, 1988). Thus, dune migration on Cape Cod may reflect a pronounced period of storm or hurricane-related disturbance of the pine-dominated forest.

Another factor that may influence eolian activity is periodic drought as documented by tree-ring time series that span the past 2000 years (e.g., Cook et al., 2014). However, drought in a mesic environment with an average precipitation of $\sim 1000 \mathrm{~mm} /$ year may result in ecologic stress and a change in species composition (Parshall et al., 2003), but not usually broad-scale landscape denudation. Dry conditions in the Northeastern US may be associated with increased forest fire (Parshall et al., 2003; Clifford and Booth, 2013) and such an ecological disturbance may lead to local landscape degradation. Drought conditions on Cape Cod, particularly associated with forest fires may be a contributory factor for increased eolian activity.

\section{METHODS: SEDIMENTOLOGY, STRATIGRAPHY AND PALEOPEDOLOGY}

Stratigraphic, sedimentologic, and pedologic observations are presented for seven sections in the informally named Cape Cod dune field (cf. Forman et al., 2008). These sequences are characterized by depositional units of eolian sand with paleosol (s) often developed in the subjacent sediment. Usually, eolian stratigraphic successions contain a conservative record of depositional periods and associated hiatuses because of the unknown completeness associated with erosion and pedogenesis (cf. Tripaldi and Forman, 2007). Thus, multiple sections were studied in this dune field located in different depositional and geomorphic contexts, which collectively may reflect the complex history of eolian deposition, landscape stability, and inferred environmental changes. At many localities tens to hundreds of meters of section are laterally exposed confirming the continuity of stratigraphic units. The Foss Woods site is beyond the area of active dune migration where dunes are vegetated and stabilized; and reflects a period of broader eolian activity. The Highway 6 and Water Tank sections expose strata through the limbs of high parabolic dunes, which accrete vertically with eolian activity and should preserve paleosols. The Trail Head, Central Valley and Single Paleosol sections are in topographically low sites and in the interior blow-out areas of the dune field. The Butte site is an erosional remnant near the margin of the dune field.

Sections were studied with attention to sedimentologic and pedogenic details. The attitude of beds was recorded to assess paleowind directions. These measurements are most meaningful where bed dips are $>5^{\circ}$. Paleo-wind directions may be variable 
when inferred from stoss side, avalanche beds as a dune advances over complex topography; derived wind directions may be at the quadrant scale. The variability in bed thickness, nature of bed contacts and the associated granulometry was recorded. Attention was focused on bedding planes and unit contacts to assess if there were hiatuses in deposition, sometimes indicated by the presence of a buried soil or localized bioturbation. The recognition and lateral tracing of a buried soil is pivotal because this stratigraphic marker reflects probably landscape stability, associated with relatively mesic conditions. We used well vetted soil stratigraphic and geomorphic approaches (e.g., Birkeland, 1999; Tripaldi and Forman, 2007). All soil colors were assessed in the dry state. Eolian stratigraphic units representing discrete depositional events were defined by either bounding buried soils or sedimentologic characteristics.

\section{METHODS: OPTICAL DATING}

Optical dating is eminently suitable for deciphering the Holocene record of eolian deposition on Cape Cod, Massachusetts. The luminescence emission is a measure of the time between the last light exposure during grain transport and deposition, and the burial period, when shielded from any further light exposure (cf. Aitken, 1992). The development of single aliquot regeneration (SAR) protocols provides improved accuracy and precision for dating the burial time of eolian quartz grains (e.g., Murray and Wintle, 2003; Wintle and Murray, 2006) and needed resolution for dating young sediments, $<500$ years old (Madsen and Murray, 2009). Most recently SAR protocols have yielded ages consistent with independent chronologic control for the past ca. 600 year on sand beds deposited within marsh sediments, associated with beach wash over during hurricane events on southern Cape Cod (Madsen et al., 2009).

The eolian strata was sampled for luminescence dating only after there is a full understanding of the sedimentology, the extent of soil development and associated lateral changes. Often, at least two samples were extracted for luminescence dating from each eolian stratigraphic unit avoiding horizons with pedogenesis, and favoring primary eolian depositional strata. Sampling for OSL dating used light tight 5-cm-diameter and 15-cm-long sections of black ABS pipe, which were easily hammered into the desired sampling level.

An a priori assumption is that quartz grains in this eolian depositional system were not uniformly solar reset because of the short distance of transport and the possible fall and winter sedimentation associated with snow cover. Single aliquot regeneration (SAR) protocols (Murray and Wintle, 2003; Wintle and Murray, 2006) were used in this study to estimate the apparent equivalent dose of the $425-500 \mu \mathrm{m}$ quartz fractions for 2646 separate aliquots (Table 1). Each aliquot contained $\sim 10-30$ quartz grains corresponding to a 2 millimeter circular diameter of grains adhered (with silicon) to a $1 \mathrm{~cm}$ diameter circular aluminum disc. Such a small number of grains/aliquot was measured to isolate the youngest, full solar-reset grain population (cf. Duller, 2008). It is suspected that $<20 \%$ of grains of each aliquot emitted light, i.e., 2-6 quartz grains.

The sands analyzed have $\mathrm{a} \mathrm{SiO}_{2}$ content of $>90 \%$ of the noncarbonate fraction and are predominantly a moderately to well sorted medium to coarse sand with $>80 \%$ quartz grains, reflecting the mineralogy of underlying Pleistocene outwash, a likely source for the eolian sand (Ockay and Hubert, 1996). The quartz fraction was isolated by density separations (at 2.55 and $2.70 \mathrm{~g} / \mathrm{cc}$ ) using the heavy liquid $\mathrm{Na}$-polytungstate and a 40-min immersion in $\mathrm{HF}(40 \%)$ was applied to etch the outer $\sim 10 \mu \mathrm{m}$ of grains, which is affected by alpha radiation (Mejdahl and Christiansen, 1994). Quartz grains were rinsed finally in $\mathrm{HCl}(10 \%)$ to remove any insoluble fluorides. The purity of quartz separate was evaluated by petrographic inspection and point counting of a representative aliquot. Samples that showed $>1 \%$ of non-quartz minerals were retreated with HF and rechecked petrographically and sieved again. In addition, the optical purity of quartz separates was tested by exposing aliquots to infrared excitation, which preferentially excites feldspar minerals or feldspathic inclusions (cf. Duller et al., 2003). Aliquots which showed infrared emissions appreciably above background counts ( $>200$ counts/s) where omitted from equivalent dose calculations.

An Automated Risø TL/OSL-DA-15 system was used for SAR analyses with light from blue diodes. Optical stimulation for all samples was completed at an elevated temperature $\left(125^{\circ} \mathrm{C}\right)$ using a heating rate of $5^{\circ} \mathrm{C} / \mathrm{s}$. All SAR emissions were integrated over the first $0.8 \mathrm{~s}$ of stimulation out of $50 \mathrm{~s}$ of measurement, with background based on emissions for the last 40- to 50-s interval. A previous study of coastal sands in southern Massachusetts documented an appreciable medium component of luminescence emissions which resulted in omission of up to $33 \%$ of aliquots for equivalent dose calculation (Madsen et al., 2009). In this study we used the threshold "fast ratio" of > 20 (cf. Durcan and Duller, 2011) to determine quantitatively aliquots that are dominated by a fast component and thus only those aliquots are included in equivalent dose calculations. The majority of aliquots $(>75 \%)$ exhibited a clear so called fast component (Figure 2) which is one of the requirements of the SAR protocols (Murray and Wintle, 2003).

A series of experiments was performed to evaluate the effect of preheating at $180,200,220,240$, and $260^{\circ} \mathrm{C}$ on isolating the most robust time-sensitive emissions and thermal transfer of the regenerative signal prior to the application of SAR dating protocols (see Murray and Wintle, 2003). These experiments entailed giving a known dose (10 Gy) and evaluating which preheat resulted in recovery of this dose. There was concordance with the known dose (10 Gy) for preheat temperatures above $200^{\circ} \mathrm{C}$ with an initial preheat temperature used of $220^{\circ} \mathrm{C}$ for $10 \mathrm{~s}$ in the SAR protocols. A "cut heat" at $160^{\circ} \mathrm{C}$ for $10 \mathrm{~s}$ was applied prior to the measurement of the test dose and a final heating at $260^{\circ} \mathrm{C}$ for $40 \mathrm{~s}$ was applied to minimize carryover of luminescence to the succession of regenerative doses. A test for dose reproducibility was also performed following procedures of Murray and Wintle (2003) with the initial and final regenerative dose yielding concordant luminescence responses (at one-sigma error) (Figure 3).

Calculation of equivalent dose by the single aliquot protocols was accomplished for 26-46 aliquots (Table 1). For all samples $65-100 \%$ aliquots were used for the final (De) distribution and age determination. Aliquots were removed from analysis because the fast ratio was $<20$ (Durcan and Duller, 2011), the recycling ratio was not between 0.90 and 1.10 , the zero dose was $>5 \%$ of 
Table 1 | Optically stimulated luminescence (OSL) modeled ages on 425-500 $\mu \mathrm{m}$ quartz grains from eolian sediments, Cape Cod National Seashore, Massachusetts.

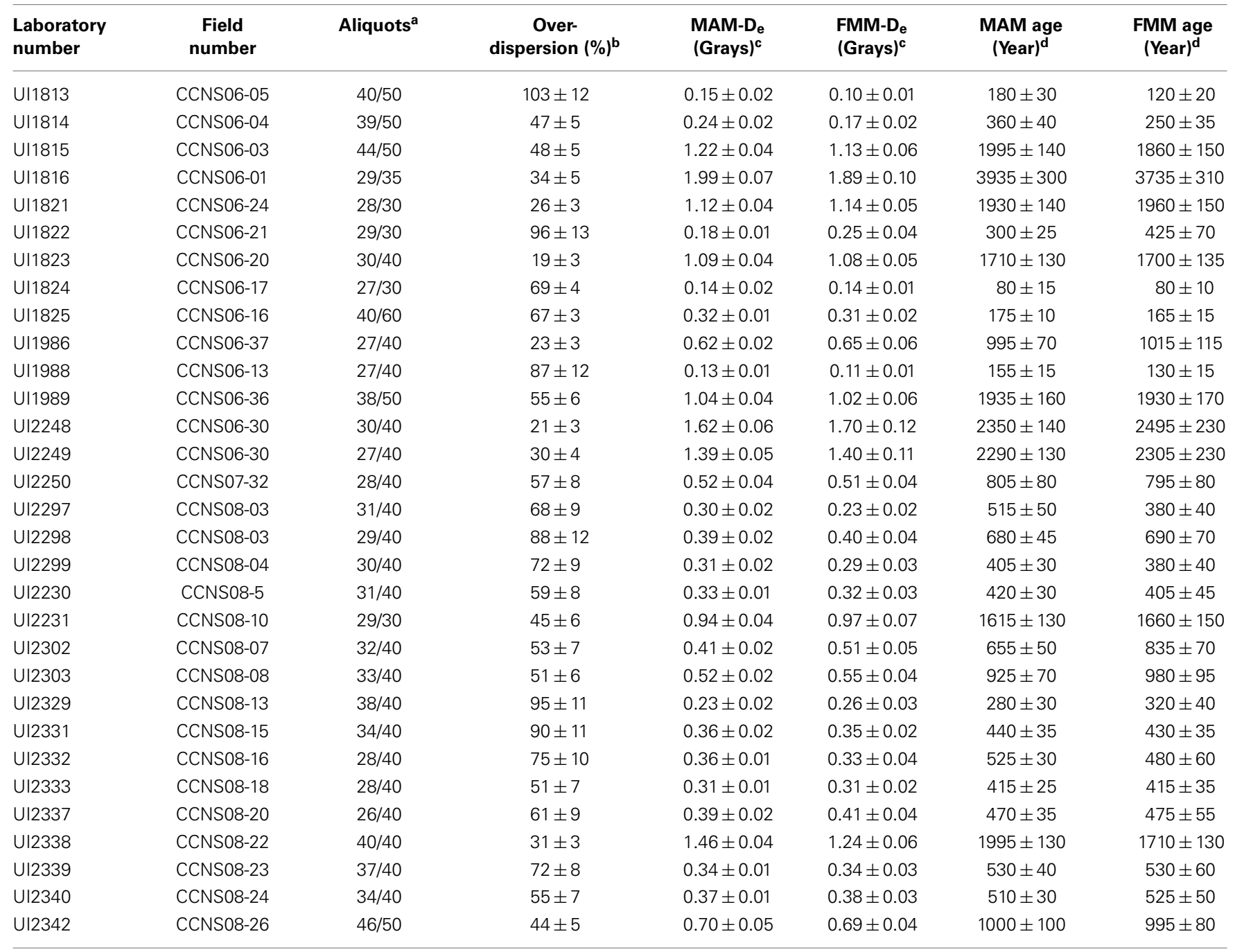

${ }^{a}$ Aliquots used in equivalent dose calculations vs. original aliquots measured.

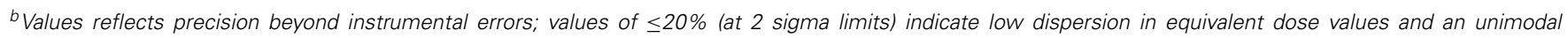
distribution.

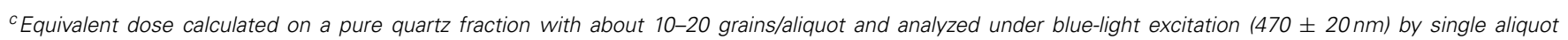

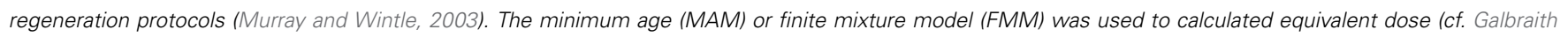
and Roberts, 2012).

d Systematic and random errors calculated in quadrature and reported errors are at one sigma; reference year for ages is AD 2000.

the natural emission, and the error in equivalent dose determination is $>10 \%$. Equivalent dose (De) distributions are log normal, highly negatively skewed and exhibited a range of overdispersion values from 23 to $103 \%$ (Table 1; Figure 4). Overdispersion values $\leq 20 \%$ are routinely assessed for small aliquots of quartz grains that are well solar reset, like far-traveled eolian and fluvial sands (e.g., Olley et al., 1998; Wright et al., 2011; Meier et al., 2013) and this value is considered a threshold metric for calculation of a $\mathrm{D}_{\mathrm{e}}$ value using the central age model of Galbraith et al. (1999). Overdispersion values $>20 \%$ may indicate mixing of grains of various ages or partial solar resetting of grains; the minimum age (three parameters) (Galbraith et al., 1999) and finite mixture models is an appropriate statistical treatment for such data (Galbraith and Green, 1990), and these models are used to calculate optical ages (Figure 4; Table 1). The accuracy of these age models are directly tested at three stratigraphic levels (Butte and Central Valley 2 sites) where there are calendar corrected ${ }^{14} \mathrm{C}$ ages (Fairbanks et al., 2005) on buried wood (Table 2) and these ages are concordant (at one sigma errors) with closely associated OSL ages (Figures 5, 6). Ages calculated by the Finite Mixture Model are favored because age subpopulations are more definitively define than by the Minimum Age Model, though ages by these computational approaches overlap at two standard deviations (Table 2). 

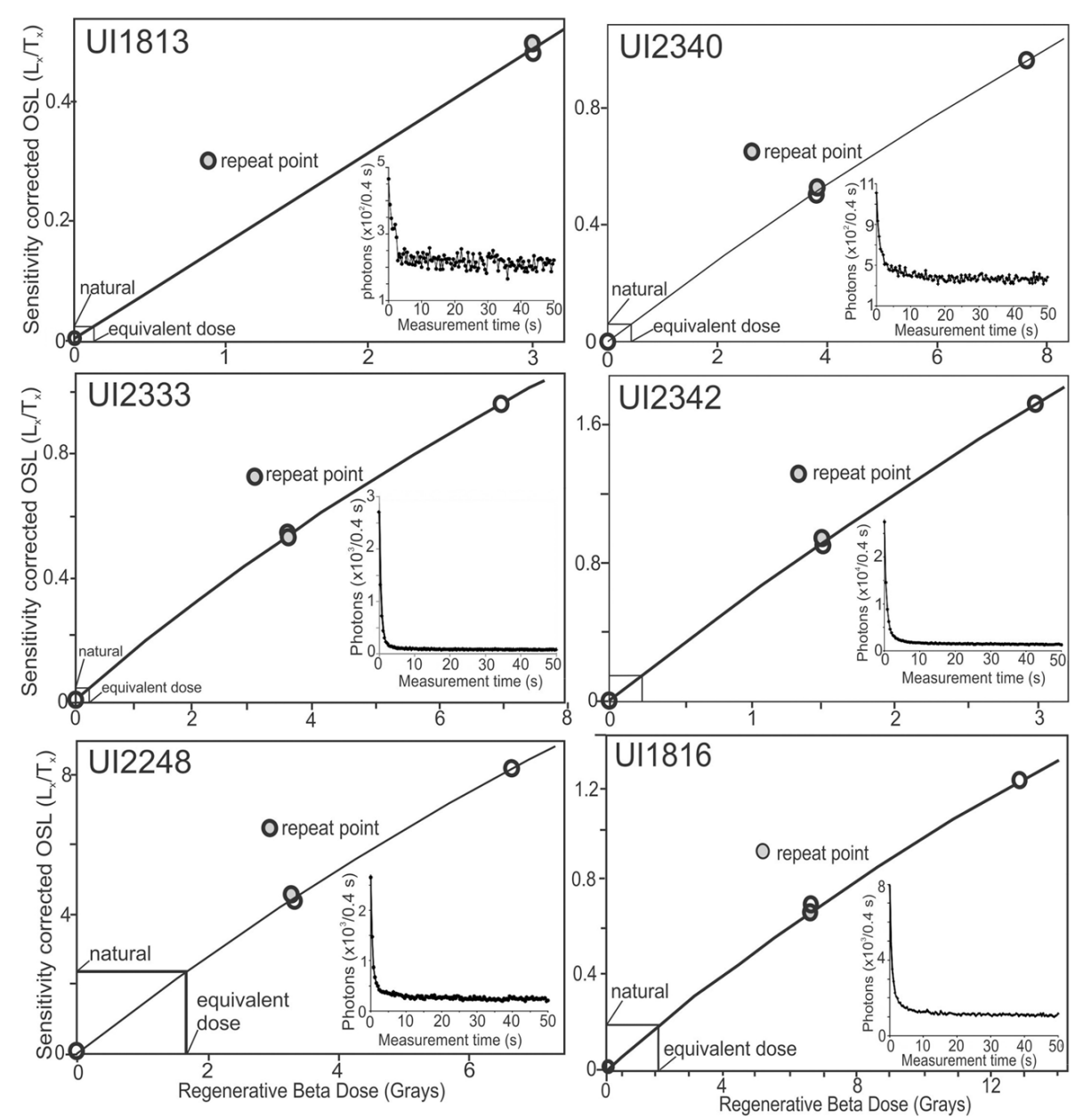

FIGURE 3 | OSL regenerative dose functions and representative shine down curves for quartz grains from Cape Cod eolian deposits.

A determination of the environmental dose rate is needed to render an optical age, which is an estimate of the exposure of quartz grains to ionizing radiation from $\mathrm{U}$ and $\mathrm{Th}$ decay series, ${ }^{40} \mathrm{~K}$, and cosmic sources during the burial period (Table 3). The $\mathrm{U}$ and Th content of the sediments, assuming secular equilibrium in the decay series and ${ }^{40} \mathrm{~K}$, were determined by ICP-MS/OES analyzed by Activation Laboratory LTD, Ontario, Canada. The beta and gamma doses were adjusted according to grain diameter to compensate for mass attenuation (Fain et al., 1999). A significant cosmic ray component between 0.09 and $0.20 \mathrm{mGy} /$ year was included in the estimated dose rate taking in to account the current depth of burial (Prescott and Hutton, 1994). A moisture content (by weight) of $5 \pm 2 \%$, or $2 \pm 1$ was used in dose rate calculations, which reflects the variability in current field moisture conditions. The datum year for all OSL ages is AD 2000 and the three ${ }^{14} \mathrm{C}$ ages reported are also corrected to this year (Table 2).

\section{RESULTS: STRATIGRAPHIC RECORD OF EOLIAN DEPOSITION BUTTE SITE $\left(42^{\circ} 4.31^{\prime} \mathrm{N} ; 7^{\circ} 10.34^{\prime} \mathrm{W}\right)$}

This site is a wind-eroded hillside forming a prominent vertical face that exposes two Spodosol-like paleosols (coniferous/mixed forest-type soil with an E and Bs horizons) intercalated with strata of eolian sand (Figure 5). The basal unit (1) is a very well sorted, light yellowish-brown (10YR 6/4), coarse sand, with 1-to-5-cm thick beds dipping down $10^{\circ}-15^{\circ}$ toward N10W, indicating deposition by north by northwest winds. A paleosol is developed in the upper $70 \mathrm{~cm}$ of unit 1 . This paleosol has a 5 -cm-thick, sandy loam, and very dark gray (10YR 3/1) Ab horizon, with weak, medium subangular-blocky structure and include wood fragments. Below the $\mathrm{Ab}$ is a $10-\mathrm{cm}$-thick, sandy, and light brownish-gray (10YR 6/2) Eb horizon. Further at depth is a 55cm-thick, yellowish brown (10YR 5/6) Bsb horizon. Rubification persists to a depth of $\sim 100 \mathrm{~cm}$ below the top of unit 1 with iron concentrations along bedding planes. Unit 2 is a very well sorted, light yellowish-brown (10YR 6/4), medium to coarse sand with 0.5 -to- $3 \mathrm{~cm}$ thick beds. The strata are often cross-bedded, dipping down $20^{\circ}-10^{\circ}$ toward N60W to N20W. A paleosol is developed in the upper $50 \mathrm{~cm}$ of unit 2 with a prominent sandy loam, very dark gray (10YR 3/1) Ab horizon which contains copious amounts of organic matter, mostly wood fragments. Subjacent buried soil horizons show modest development with a $24 \mathrm{~cm}$ thick, sandy, light yellowish-brown (10YR 6/2) Eb and a 


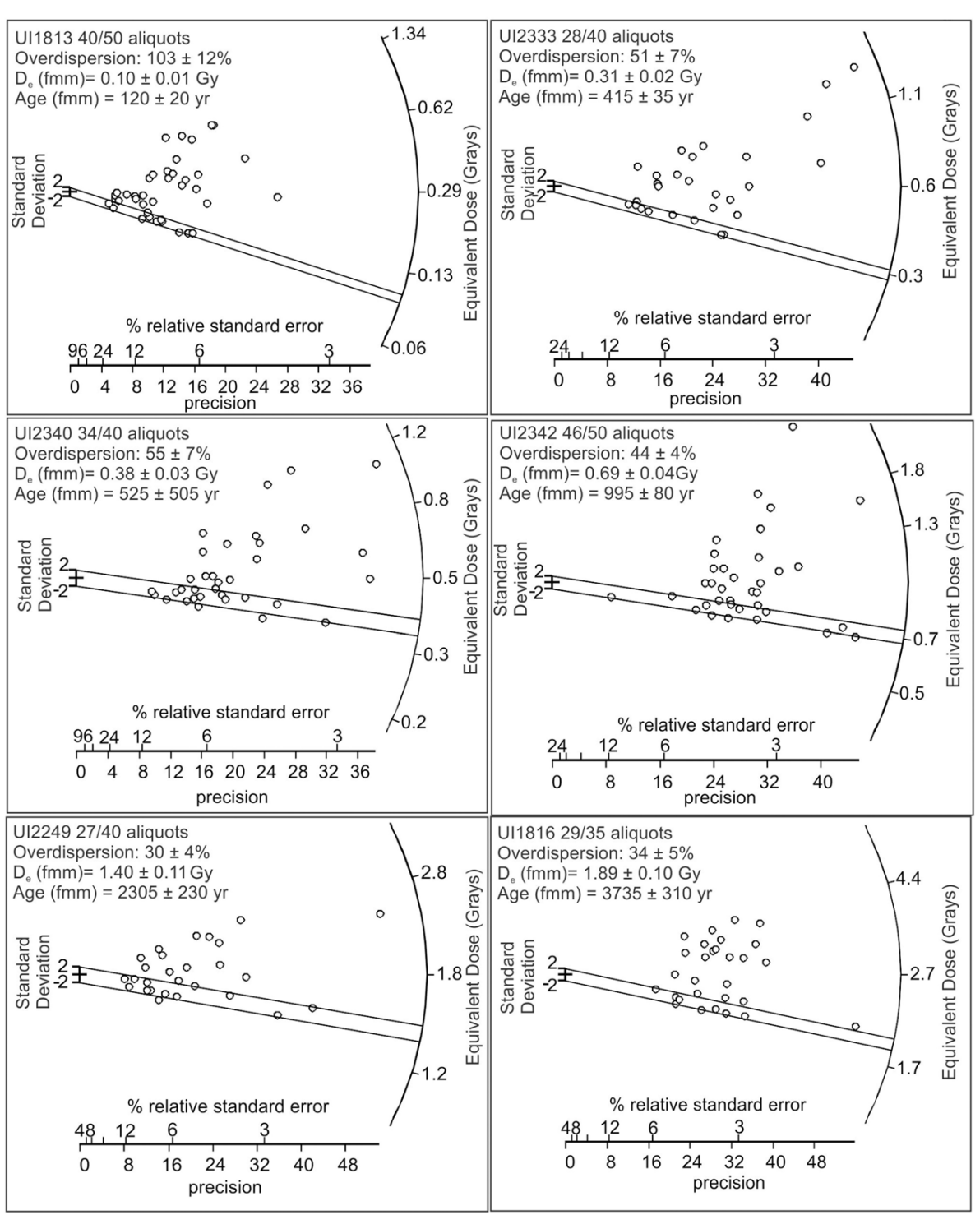

FIGURE 4 | Radial plots of equivalent dose values for quartz grains from Cape Cod eolian sand deposits. The two parallel lines designate the lowest equivalent dose population defined by a finite mixture model (Galbraith and Green, 1990).

Table 2 | Radiocarbon ages and data for wood fragments collected from buried soils in Cape Cod National Seashore, Massachusetts USA.

\begin{tabular}{lccccc}
\hline Field number & Lab number & $\boldsymbol{\delta}^{\mathbf{1 3}} \mathbf{C}$ & Laboratory reported age (year) & Calendar corrected age (year) & Corrected to AD 2000 (year) $^{\mathbf{a}}$ \\
\hline CCNS06-40 & AA73365 & -26.7 & $193 \pm 32$ & $201 \pm 89$ & $251 \pm 89$ \\
CCNS06-41 & AA73366 & -27.4 & $971 \pm 34$ & $898 \pm 42$ & $948 \pm 42$ \\
CCNS08-09 & ISGSA1131 & -25.9 & $1085 \pm 20$ & $1005 \pm 37$ & $1050 \pm 37$
\end{tabular}

${ }^{a}$ Fairbanks et al. (2005).

$30 \mathrm{~cm}$ thick, sandy CBsb, with bedding evident, accentuated by yellowish brown (10YR 5/5) iron concentrations along bedding planes. The top unit (3) is a very well sorted, very pale-brown (10YR 7/4), medium to coarse sand with 5 -to- $0.5 \mathrm{~cm}$ thick beds dipping down $10^{\circ}-15^{\circ}$ toward $\mathrm{N} 60 \mathrm{~W}$, the inferred direction of paleowinds. Quartz grains from bedded levels in units 1,2 , and
3 gave optical ages of $1930 \pm 170$ year (UIC1989), $985 \pm 70$ year (UIC1986) and $130 \pm 15$ year (UIC1988) (Table 1), respectively. Wood fragments from the buried $\mathrm{Ab}$ horizons in unit 1 and unit 2 yielded corresponding calendar corrected ${ }^{14} \mathrm{C}$ ages of $948 \pm 42$ year BP (AA-73366) and $251 \pm 89$ year BP (AA-73365) (Table 1; Figure 5). 


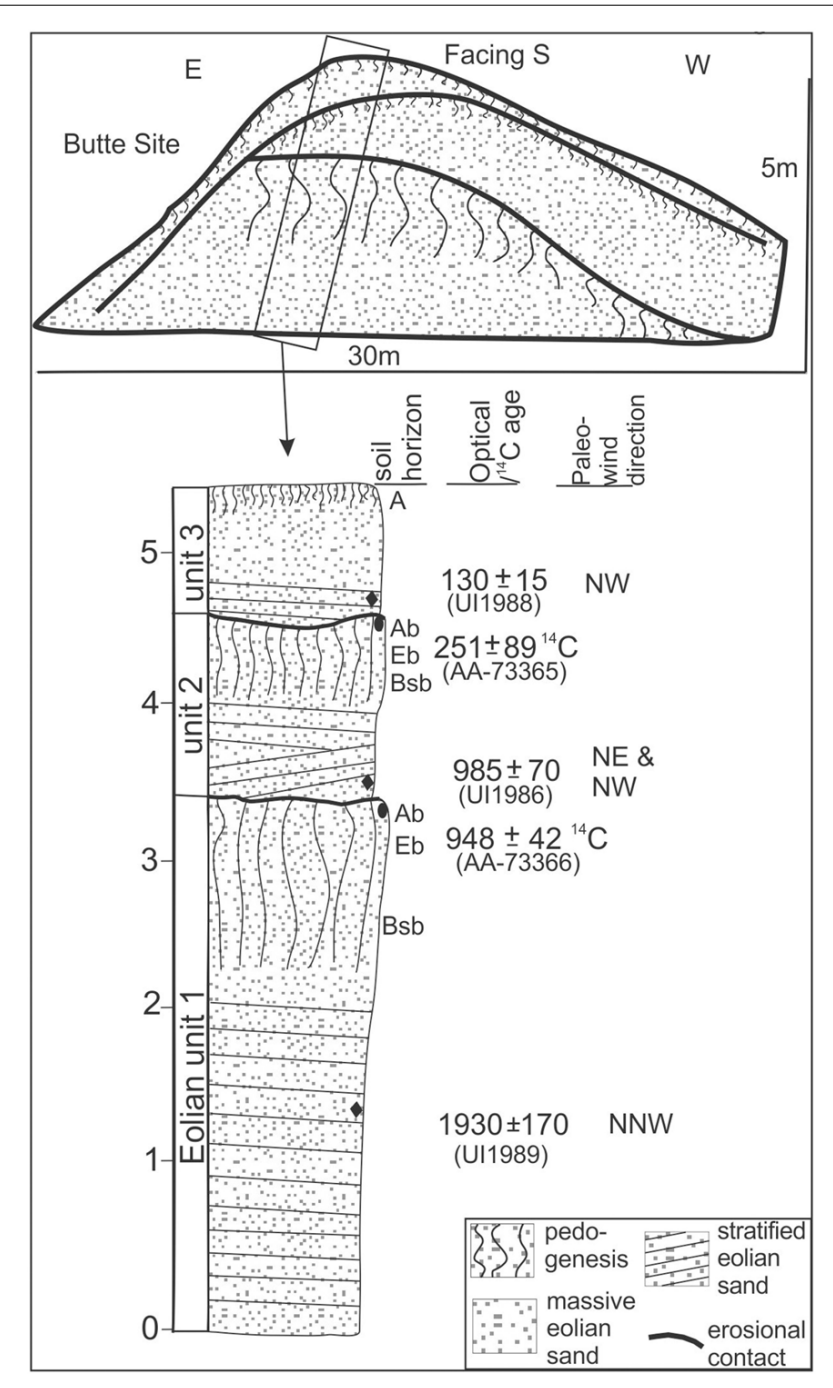

FIGURE 5 | Stratigraphy, buried soils, paleowind directions and associated ${ }^{14} \mathrm{C}$ and $\mathrm{OSL}$ ages for the Butte site, Cape Cod National Sea Shore, Massachusetts. The datum year for all ages is AD 2000.

\section{SINGLE PALEOSOL SITE $\left(42^{\circ} 4.16^{\prime} \mathrm{N} ; 7^{\circ} \mathbf{1 0 . 5 8}^{\prime} \mathrm{W}\right)$}

A wind-eroded, tree-covered hillside exposes two eolian sand units separated by a truncated paleosol (Figure 6). The lowest eolian unit (1) is a very well sorted, very pale brown (10YR $7 / 4$ ), medium to coarse sand with 3-to-10-cm thick, asymptotic beds dipping $25-30^{\circ}$ toward the southeast (S55E). These beds are interpreted to reflect avalanche processes and are associated with winds from the northwest. The top of eolian unit 1 is demarcated by a Spodosol-type paleosol. This paleosol has a 2-cm-thick, very dark brown (10YR 3.5/2), and silty sand Ab horizon. Subjacent is a $7 \mathrm{~cm}$ thick, very pale brown (10YR 7/4) Eb horizon, with single-grain structure. Further at depth is a 50 -cm-thick CBsb horizon with a brownish yellow (10YR6/6) matrix and reddish yellow (7.5YR6/6) mottles. Eolian unit 2 is a pale brown (10YR $7 / 4$ ), very well sorted medium sand with $1-$ to-3-cm thick inclined beds, parallel with the underlying paleosol surface. These eolian beds down dip $20-25^{\circ}$ toward N40E and indicate that sand was banked against the subjacent paleosol from the northeast. Quartz grains from unit 1 yielded ages of $995 \pm 80$ year (UIC2342); optical ages for unit 2 are $530 \pm 60$ year (UIC2339) and $525 \pm 50$ year (UIC2340) (Table 1).

\section{CENTRAL VALLEY SITE $\left(42^{\circ} 4.19^{\prime} \mathrm{N} ; \mathbf{7 0}^{\circ} 1 \mathbf{1 0 . 2 3}^{\prime} \mathrm{W}\right)$}

The Central Valley site is in a topographically low area in the dune field, where dune movement has confounded drainage and in places dammed channels forming seasonal wetlands (Figure 1). This site shows recent blow-out dunes and includes two sections (Introduction and Geomorphic Context) $\sim 50 \mathrm{~m}$ apart that exposes a sequence of two Spodosol-like paleosols and intercalated eolian sand which can be visibly traced (Figure 6). In section Introduction a pair of "welded" (Ruhe and Olson, 1980) paleosols occurs in the basal $1 \mathrm{~m}$. The lowest-most paleosol in unit 1 is characterized by a $7 \mathrm{~cm}$ thick, sandy silt and grayish brown (10YR $5 / 2$ ) Ab horizon. Subjacent is a $13 \mathrm{~cm}$ thick, very pale-brown (10YR 7/4) Eb horizon and below a $10 \mathrm{~cm}$ thick, reddish yellow (7.5YR6/6) Bsb horizon. The overlying paleosol in unit 2 has similar morphology to unit 1 paleosol. In section Introduction the overlying unit 2 is a light yellowish-brown (10YR 6/4), very well sorted medium sand with a variety of $\mathrm{cm}$-scale interbeds (Figure 5) in a sharp, erosional contact with a subjacent buried soil. The bedding characteristics of unit 3 are subdivided into five bedsets (a-e) and described from bed base to top of unit. Laminations in bedset a from 1.0 to $2.0 \mathrm{~m}$ depth are $5-15 \mathrm{~cm}$ thick and asymptotic with dipping down $20-25^{\circ}$ toward the westsouthwest (S70W) which reflects avalanche beds of a migrating dune from the east to northeast. Bedset $b$ from 2.0 to $2.9 \mathrm{~m}$ depth is well-sorted, homogenous and loose medium sand and appears to be extensively burrowed. Bedset c from 2.9 to $3.25 \mathrm{~m}$ depth has 2 to $4 \mathrm{~cm}$ thick beds dipping down $25-20^{\circ}$ from the southwest (S25W), and are probably avalanche beds accreted from paleowinds from the north to northeast. Bedset d from 3.25 to $3.85 \mathrm{~m}$ depth shows 1-to-5-cm thick, asymptotic beds dipping downward $25-30^{\circ}$ from the southwest ( $330 \mathrm{~W}$ to $\mathrm{S} 65 \mathrm{~W}$ ); these are dune avalanche beds and indicate paleowinds from the northeast. Bedset e from 3.85 to $4.40 \mathrm{~m}$ depth has $2-5 \mathrm{~cm}$ thick beds of mostly coarse sand dipping downward $10-15^{\circ}$ from the east, the direction of paleo-winds. The upper $60 \mathrm{~cm}$ of unit 3 is massive from burrowing and pedogenesis and exhibits an $\mathrm{A} / \mathrm{C}$ profile, with American Beach Grass (Ammophila breviligulata) on the surface. Quartz grains from bedded intervals from unit 3 gave optical ages of $480 \pm 65$ year (UIC2332), $415 \pm 40$ year (UIC2333), and $475 \pm 55$ year (UIC2337) (Table 1).

Central Valley site 2 also exposes two paleosols which are physically traced to the two paleosols of site 1 (Figure 6). The paleosols at site 2 have clear stratigraphic separation with bedded eolian sand and are targets for optical dating. The paleosol in unit 1 is characterized by a $5 \mathrm{~cm}$ thick, very dark gray $(10 \mathrm{YR} 3 / 1)$ and slightly silty sand $\mathrm{Ab}$ horizon with abundant wood fragments. Below the $\mathrm{Ab}$ is a $15 \mathrm{~cm}$ thick, very pale brown (10YR 7/3) Eb horizon, with single grain structure and a $50 \mathrm{~cm}$ thick Bsb horizon with strong brown (7.5YR5/6) color and weak, small subangularblocky structure. The pedogenic imprint is diffuse (BCsb to $\mathrm{Cb}$ ) at depths below $70 \mathrm{~cm}$ into unit 1 with strong brown (7.5YR 4/6) mottles decreasing with depth, concomitant with the preservation 


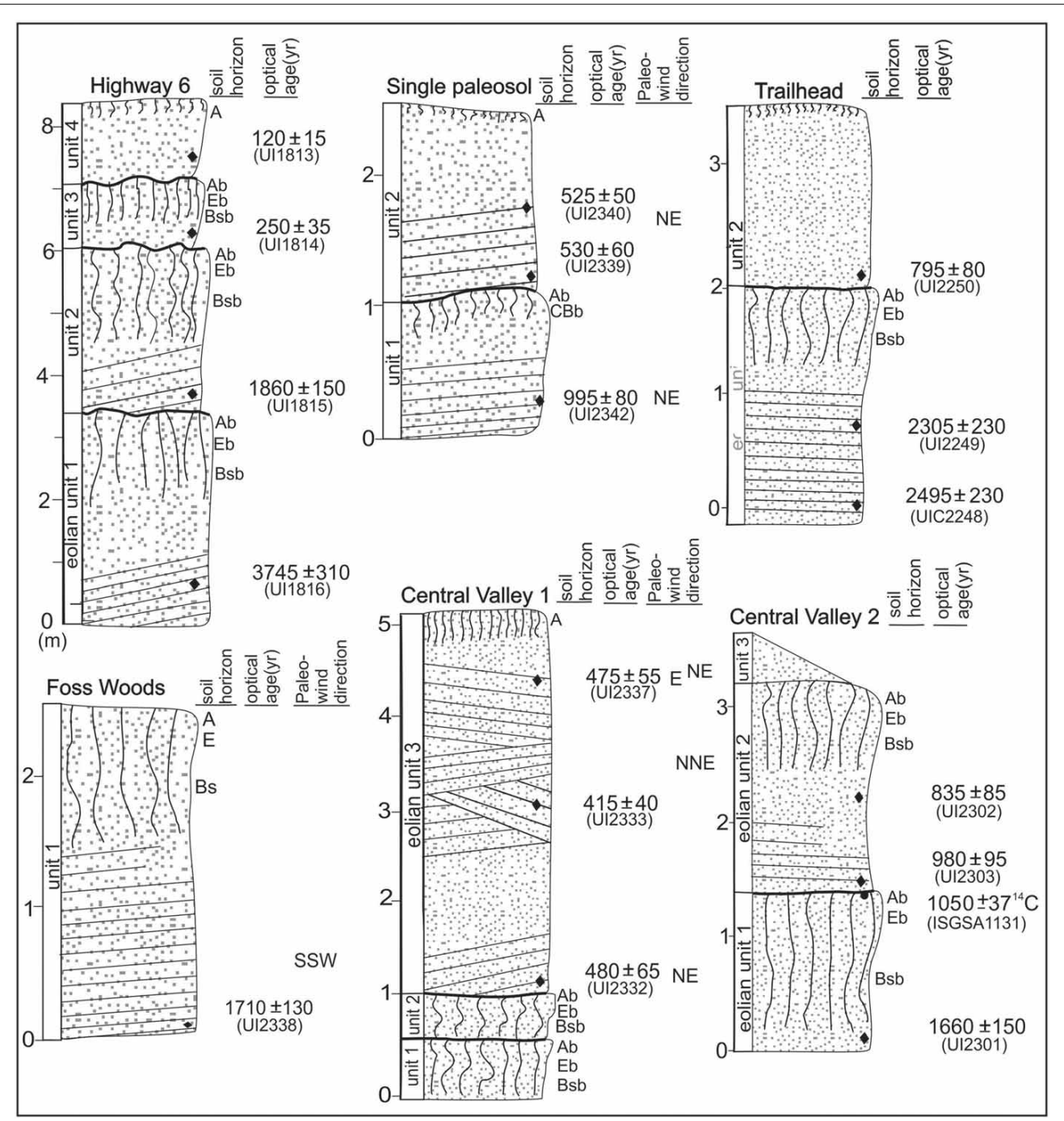

FIGURE 6 | Stratigraphy, buried soils, paleowind directions and associated ${ }^{14} \mathrm{C}$ and OSL ages for Highway 6, Single Paleosol, Trailhead, Foss woods site and Central Valley sites, Cape Cod National Sea Shore, Massachusetts. The datum year for all ages is AD 2000.

of centimeter-scale bed remnants, 30-40 cm long. The over lying unit 2 is a light yellowish-brown (10YR 6/4), very well sorted, coarse to medium sand with $10-30 \mathrm{~cm}$ long, horizontally stratified bed remnants, increasing in abundance below $1 \mathrm{~m}$ into the unit. The basal contact between unit 2 eolian sand and subjacent paleosol of unit 1 is sharp. Unit 2 paleosol exhibits a $6 \mathrm{~cm}$ thick, very dark grayish-brown (10YR 3/2), sandy silt Ab horizon with moderate, medium subangular-blocky structure. In places this $\mathrm{Ab}$ horizon shows millimeter-scale laminations of reworked organic matter and medium sand grains. Below this $\mathrm{Ab}$ is a 17cm-thick, pale brown (10YR 6/3) Eb horizon with single-grain structure. Subjacent to the Eb horizon is a $43 \mathrm{~cm}$ thick Bsb horizon with reddish-yellow (7.5YR6/6) color and moderate, medium subangular-blocky structure. The paleosol in unit 2 is covered by a variable thickness $(0-100 \mathrm{~cm})$ of recent, loose sand. Quartz grains from bedded intervals from unit 1 and unit 2 yield optical ages of $1660 \pm 150$ year (UIC2301) and $980 \pm 95$ year (UIC2303) and $835 \pm 85$ year (UIC2302), respectively (Table 1 ). Wood from the
$\mathrm{Ab}$ of the paleosol in unit 1 gave the calendar corrected radiocarbon age of $1060 \pm 37$ year BP (ISGS A1131) (Table 2), which is consistent with the overlying optical age of $980 \pm 95$ year (UIC2303).

\section{TRAILHEAD SITE $\left(42^{\circ} 4.13^{\prime} \mathbf{N} ; 7^{\circ} \mathbf{9 . 8 0 ^ { \prime }} \mathrm{W}\right)$}

This site is adjacent to a wetland and is a wind-eroded almost vertical exposure, extended by excavation (Figure 6). At about $3.5 \mathrm{~m}$ depth from the surface the groundwater table was encountered. Unit 1 is a very well sorted, light-yellowish brown (10YR6/4), medium sand with centimeter-scale horizontal bedding in the lower $1.0-1.25 \mathrm{~m}$ of unit 1 . Bedding is accentuated by ironstaining and there is a noticeable horizontal concentration of a brown (7.5YR 4/4), iron-rich secondary deposit at $0.75 \mathrm{~m}$ depth. A Spodosol-like paleosol occurs in the upper $70 \mathrm{~cm}$ of unit 1 and is characterized by a 10 -cm-thick, black (10YR 2/1), and silty sand Ab horizon. Subjacent to this Ab is a 20-cm-thick, sandy, and light gray (7.5YR 7/1) Eb horizon and 40-cm-thick, 
Table 3 | Dose rate data for eolian sediments from Cape Cod National Seashore, Massachusetts.

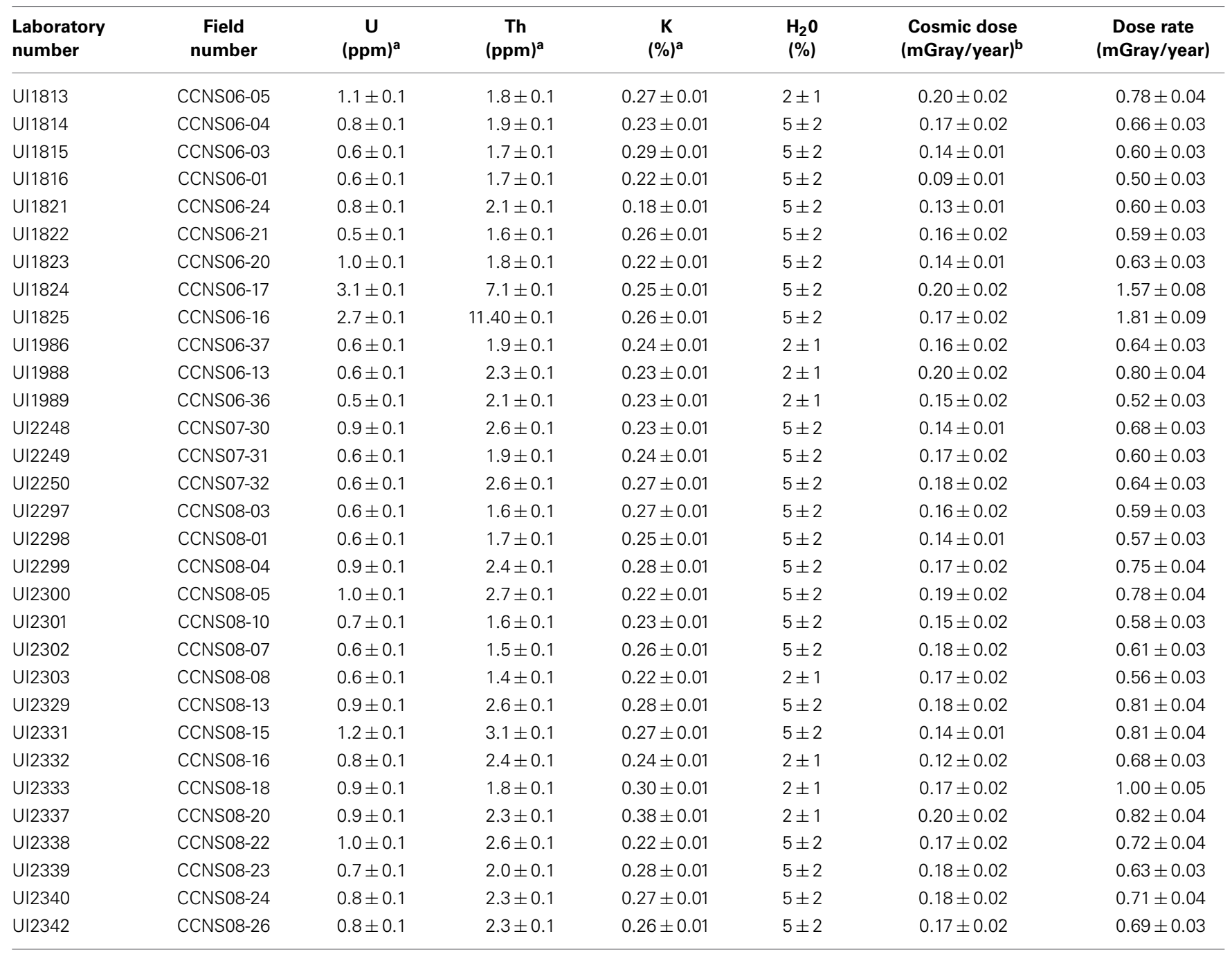

${ }^{a} U$, Th, and K content analyzed by inductively coupled plasma-mass spectrometry analyzed by Activation Laboratory LTD, Ontario, Canada.

${ }^{b}$ From Prescott and Hutton (1994).

sandy, brown (7.5YR 4/4) Bsb horizon. The overlying unit 2 is a very well sorted medium sand with centimeter-scale horizontal to subhorizontal bedding that is in sharp contact with subjacent paleosol. The upper $30 \mathrm{~cm}$ of section supports American Beach Grass (Ammophila breviligulata) and reflects recent eolian sand additions. Quartz grains from the bedded levels in unit 1 and in unit 2 yielded optical ages of $2495 \pm 230$ year (UIC2248) and $2305 \pm 230$ year (UIC2249) and $795 \pm 80$ year (UIC2250) (Table 1), respectively.

\section{HIGHWAY 6 SITE $\left(42^{\circ} 3.69^{\prime} \mathrm{N} ; 7^{\circ} 9.13^{\prime} \mathrm{W}\right)$}

This site is a road cut into the southern flank of the active dune field and exposes three Spodosol-like paleosols interbedded with eolian sand (Figures 5, 7A) The lowest most unit (1) is a yellowish brown (10YR 5/4), very well sorted medium sand with centimeter-scale horizontal beds, many accentuated by clay lamellae. A paleosol is developed in the upper $1.65 \mathrm{~m}$ of unit 1. This paleosol has a $6 \mathrm{~cm}$ thick, sandy loam, and very dark grayish-brown (10YR 3/1) Ab with weak, medium subangular-blocky structure. The upper $2 \mathrm{~cm}$ of the $\mathrm{Ab}$ shows millimeter-scale laminations of reworked Ab horizon material. Below the $\mathrm{Ab}$ horizon is an $\sim 34 \mathrm{~cm}$ thick, sandy, and pale brown (10YR 6/3) Eb horizon with single grain structure and a glossic lower boundary. Subjacent to the Eb horizon is a $60-\mathrm{cm}$-thick brown (7.5YR 4/4), sandy Bsb, with medium subangular-blocky structure.

Unit 2 is in sharp contact with subjacent paleosol and is a yellowish brown (10YR 5/4), very well sorted medium sand with centimeter-scale horizontal to subhorizontal bedding, most evident in the basal $140 \mathrm{~cm}$ of the unit. A paleosol dominates in the upper $170 \mathrm{~cm}$ of unit 2 (Figure 7B). This buried soil has a $8 \mathrm{~cm}$ thick, dark brown (7.5YR 3/2), and sandy loam Ab with moderate subangular-blocky structure. Subjacent to the Ab horizon is a 27-cm-thick, sandy, and light brown (7.5YR 6/4) Eb horizon with single grain structure. Below the Eb horizon is a 45-cm-thick, strong brown (7.5YR 4/6) Bsb horizon with small 


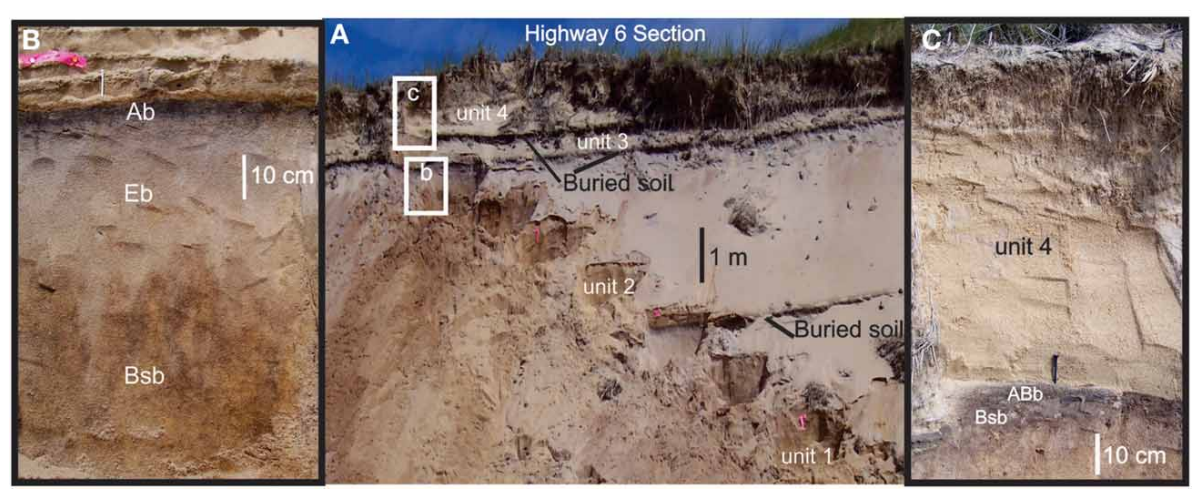

FIGURE 7 | (A) Photograph of the Highway 6 site showing three buried soils. (B) (B) Photograph shows buried soil in the top of unit 2. (C) Photograph shows buried soil in top of unit 3 and overlying unit 4 eolian sand.

subangular-blocky structure. This Bsb horizon is dominated by brown mottles (7.5YR 4/2) which continue with decreasing frequency from a depth of $80-170 \mathrm{~cm}$ below the top of unit $2(\mathrm{BCb})$, where bedding becomes evident.

Unit 3 is a brown (10YR 5/3), very well sorted, medium to coarse sand and is in sharp contact with subjacent paleosol of unit 2. Intraclasts composed of Ab horizon material are common in the lower $10 \mathrm{~cm}$ and are probably derived from the subjacent paleosol. Centimeter-scale bedding remnants are preserved in the lower $50 \mathrm{~cm}$ of unit 3 . A weak paleosol, compared to paleosols developed in units 1 and 2, occurs in the upper $50 \mathrm{~cm}$ of unit 3 (Figure 7C). This paleosol has a 6-cm-thick, slightly silty sand, and dark gray (10YR 4/1) Ab with medium subangular-blocky structure. Subjacent to the Ab is a $10-\mathrm{cm}$ thick, sandy and very pale-brown (10YR 7/4) Eb horizon with single grain structure. Rubification in the $\mathrm{BCb}$ horizon occurs to 20 below the Eb horizon with a reddish-yellow (7.5YR 6/4) matrix and brown (7.5YR 5/4) iron concentrations along bedding planes. The uppermost unit (4) is a light yellowish-brown and a very well sorted medium sand in abrupt contact with subjacent paleosol of unit 2 (Figure 7C). Centimeter-scale horizontal to subhorizontal beds are common throughout unit, though laterally discontinuous. This surface unit shows a weak and discontinuous A horizon with roots and rhizomes of American Beach Grass which are common in the upper $20 \mathrm{~cm}$ of unit 4 (Figure 7C). Quartz grains from units 1-4 yielded optical ages of $3745 \pm 310$ year (UIC1816), $1860 \pm 150$ year (UIC1815), $250 \pm 25$ (UIC1814), and $120 \pm 15$ year (UIC1813) (Table 1), respectively.

\section{FOSS WOODS SITE $\left(42^{\circ} 3.85^{\prime} \mathrm{N} ; 7^{\circ} 9.76^{\prime} \mathrm{W}\right)$}

This site is outside the active area of parabolic dune migration and is a shallow barrow pit into an arm of a tree-covered parabolic dune (Figures 1, 6). Exposed below a Spodosol-type surface soil are centimeter-scale low-angle cross-beds of a well sorted medium to coarse sand. The bedding is accentuated by a secondary accumulation of iron (brown; 7.5YR 4/4), which diminishes below $2.1 \mathrm{~m}$ depth where unaltered, light yellowish brown (10YR 6/4), and very well sorted medium eolian sand occurs. Beds dip downward at $10^{\circ}$ toward the S75W in places and indicates accretion by winds from the west to southwest. Medium quartz grains from $2.3 \mathrm{~m}$ depth yield the optical age of $1710 \pm 130$ year (UIC2338) (Table 1).

\section{WATER TANK SITE $\left(42^{\circ} 4.71^{\prime} \mathrm{N} ; 7^{\circ} \mathbf{9 . 5 7 ^ { \prime } \mathrm { W } )}\right.$}

This site is at the margin of recently active parabolic dunes (cf. Forman et al., 2008). Presented are two sections (Introduction and Geomorphic Context) which are separated by about $60 \mathrm{~m}$ (Figure 8). These sites are blow-out exposed hill sides that show two paleosols and three intercalated eolian sand units. Section Introduction shows one compound paleosol and two eolian stratigraphic units. The bottom unit (1) in section Introduction is a very well sorted medium to coarse sand with $1-5 \mathrm{~cm}$ thick, asymptotic beds, down dipping $25-30^{\circ}$ toward the southeast (S60E); these are dune avalanche beds and indicate winds from the northeast. A paleosol is developed in the approximately upper $1 \mathrm{~m}$ of unit 1 . This paleosol has a $10 \mathrm{~cm}$ thick, sandy loam, and very dark gray (10YR 3/1) Ab with moderate, medium subangular-blocky structure and a glossic lower boundary. Below the $\mathrm{Ab}$ is a 25-cm-thick, sandy, and grayish brown (10YR 5/2) Eb horizon. Further at depth is a 50 -cm-thick and dark yellowishbrown (10YR 4/6) Bsb horizon. Unit 2 is thin $(15 \mathrm{~cm})$ and composed of discontinuous strata of very well-sorted medium to coarse brown (10YR 5/3) sand; many particles are re-deposited $\mathrm{Ab}$ horizon material. A weak paleosol is developed in the upper $5 \mathrm{~cm}$ of unit 2 and is characterized by a fine to very fine sand $A b$ horizon, with moderate, small subangular-blocky structure. This $\mathrm{Ab}$ is in places "welded" (Ruhe and Olson, 1980) to the subjacent paleosol in unit 1 . The top unit (3) is a very well sorted medium sand with 0.5 -to-2.0-centimeter thick beds that down dip 10-20 toward the east-northeast $(\mathrm{E} 5 \mathrm{~N}-\mathrm{E} 30 \mathrm{~N})$; the direction of paleowinds. Quartz grains from units 1, 2, and 3 yielded optical ages of $1960 \pm 150$ year (UIC1821), $690 \pm 70$ year (UIC2298) and $380 \pm 40$ year (UIC2297), $380 \pm 40$ (UI2299) and $405 \pm 45$ year (UIC2300) (Table 1), respectively.

Section Geomorphic Context shows more stratigraphic separation between paleosols and three eolian sand units. The basal unit (1) in section Geomorphic Context is a light yellowishbrown (10YR 6/4), very well sorted, medium sand with 2-to-6-cm thick beds, down dipping $30-25^{\circ}$ toward the southeast (S55E 


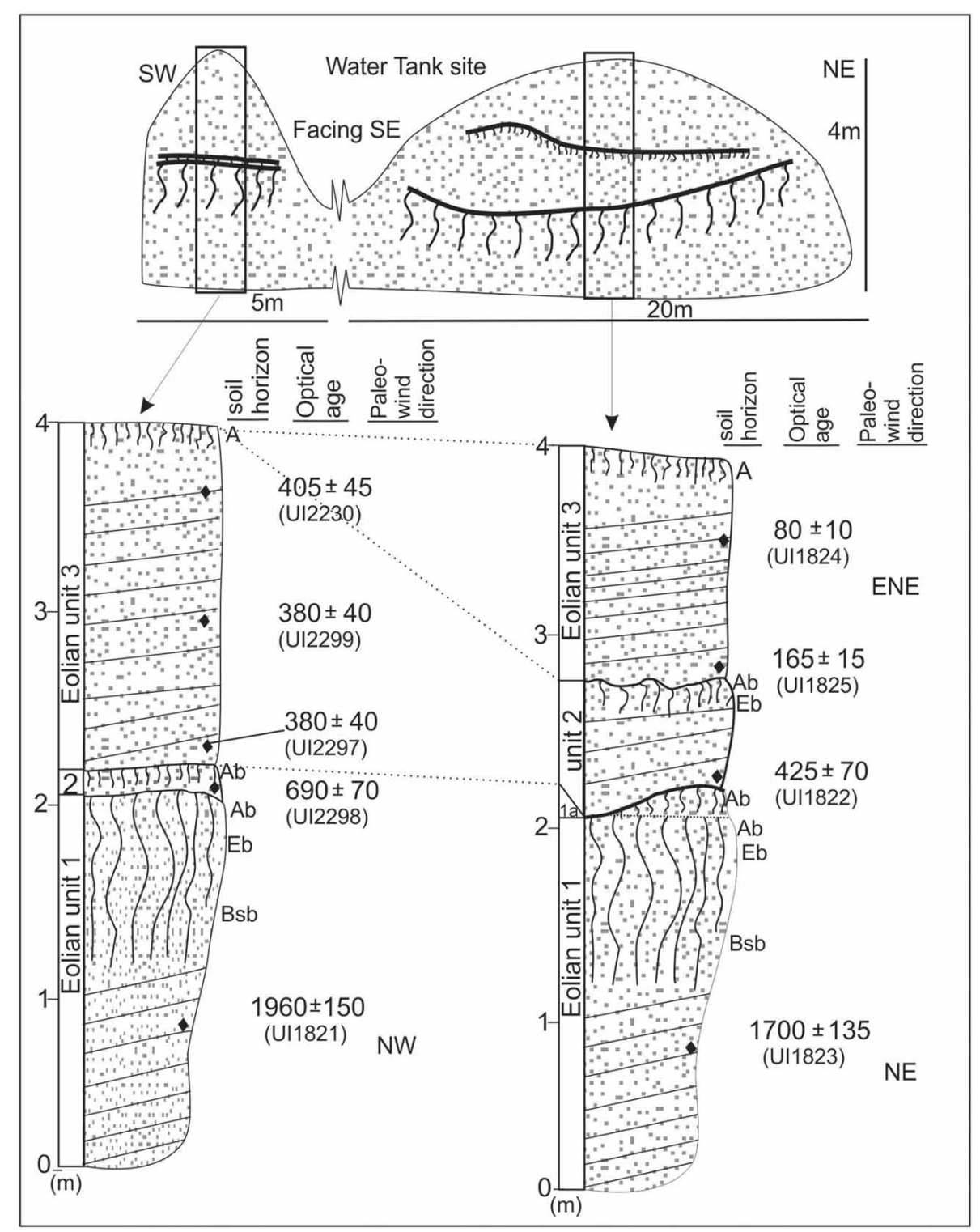

FIGURE 8 | Stratigraphy, buried soils, paleowind directions and associated OSL ages for the Water Tank site, Cape Cod National Sea Shore,

Massachusetts. The datum year for all ages is AD 2000.

to S20E). These steeply dipping beds reflect avalanche processes and are associated with winds from the northwest. A paleosol is developed in the upper $45 \mathrm{~cm}$ of unit 1 . This paleosol has a 12-cm-thick, fine sand, and very dark gray (10YR 3/1) Ab, with moderate, medium subangular-blocky structure. The upper $5 \mathrm{~cm}$ of the $\mathrm{Ab}$ exhibits millimeter-scale laminations of reworked $\mathrm{Ab}$ horizon material. Below the $\mathrm{Ab}$ is a $25-\mathrm{cm}$-thick, sandy, and light gray (10YR 7/2) Eb horizon. Further at depth is an 8-cm-thick, yellowish brown (10YR 5/4) Bsb horizon. Rubification persists to a depth of $\sim 125 \mathrm{~cm}$ below unit 1 top with iron concentrations along bedding planes. Unit 2 is a light yellowish-brown (10YR $6 / 4)$, very well sorted, medium to coarse sand with discontinuous millimeter-to-centimeter-scale, low-angle cross beds. Beds parallel the underlying paleosol and strata in the lower $5 \mathrm{~cm}$ of unit 2 and contain reworked particles from a dark brown $\mathrm{Ab}$ horizon, probably from a subjacent buried soil. A weakly developed paleosol occurs in the upper $4 \mathrm{~cm}$ of unit 2 with a dark grayish-brown (10YR 4/2), sandy loam Ab horizon. The upper most unit (3) is a pale brown (10YR 6/3), very well sorted, medium to coarse sand with low angle cross-beds. The basal $5 \mathrm{~cm}$ of unit 3 contains intraclasts and particles of the subjacent paleosol. This surface unit shows a grayish brown (10YR 5/2) discontinuous A horizon and the dominance of American Beach Grass (Ammophila breviligulata) in the upper $20 \mathrm{~cm}$. Quartz grains from stratified levels in units 1,2 , and 3 returned optical ages of $1700 \pm 135$ year (UIC1823), $425 \pm 70$ year (UIC1822), and $165 \pm 20$ year (UIC1825) and $80 \pm 10$ year (UIC1824) (Table 1). 


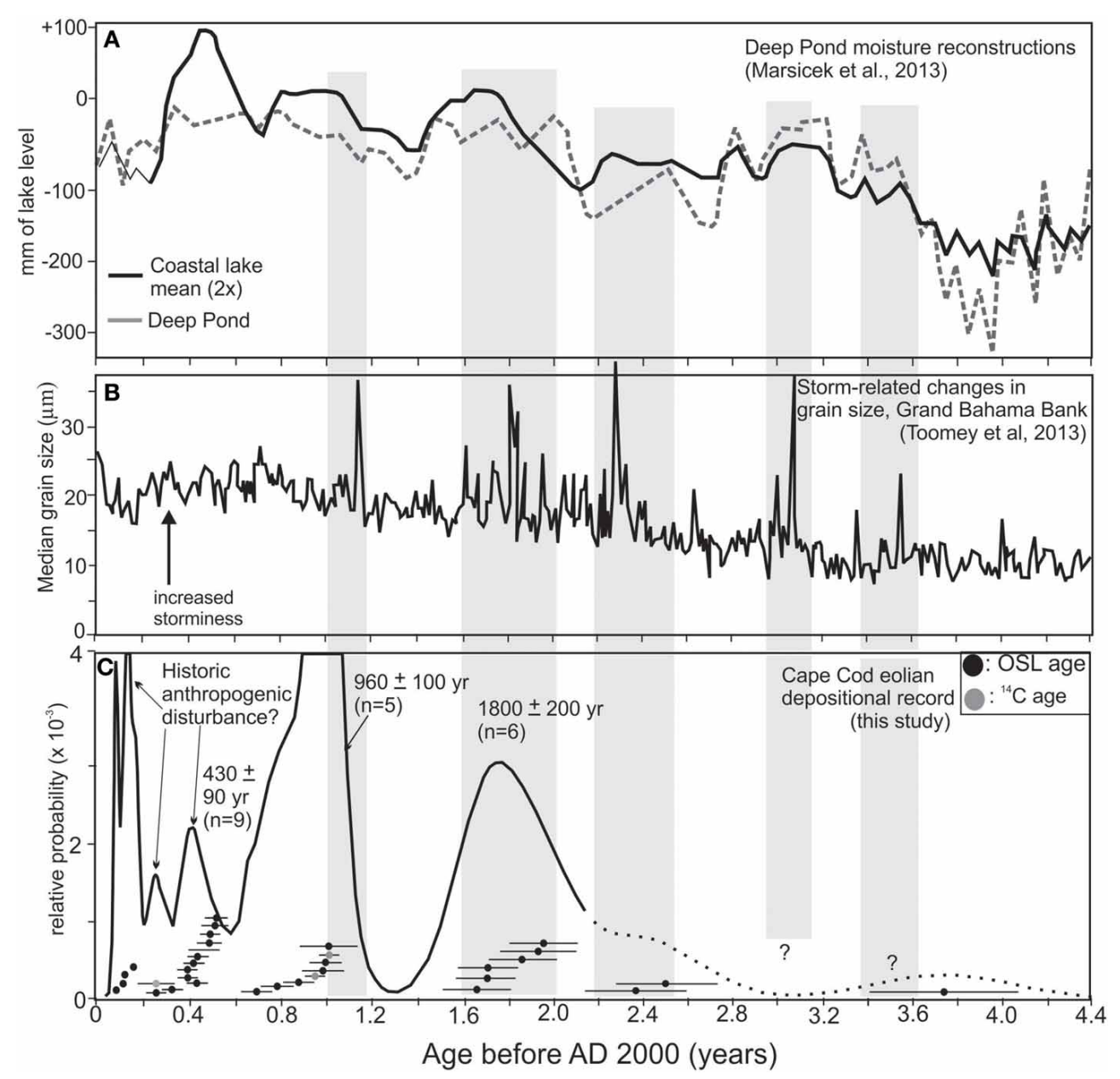

FIGURE 9 | (A) Moisture reconstruction for Deep Pond, Cape Cod and New England coastal mean for moisture (Marsicek et al., 2013). (B) Proxy record of storminess/hurricanes from grain size changes Grand Bahama Bank (Toomey et al., 2013). (C) Probability density distribution of OSL and ${ }^{14} \mathrm{C}$ ages for eolian depositional events at Cape Cod National Sea Shore. Gray bars are inferred periods of heightened storminess that are broadly coincident with periods of dune movement on Cape Cod.

\section{DISCUSSION}

Stratigraphic, sedimentologic and geochronologic data indicate that there may be six distinct periods of eolian deposition in the Cape Cod dune field (Figure 9). The oldest recognized depositional event is at the base of the Highway 6 section, where quartz grains yielded an OSL age of $3.7 \pm 0.3 \mathrm{ka}$ (Figure 6). This is a single site, with one OSL age, and thus it is unknown how pervasive is this early eolian depositional event. Lacustrine sediment cores from the northeastern U.S. show a decline in Hemlock (Tsuga sp.), a decrease in lake level, or an increase in clastic sedimentation ca. $5.5-3.8 \mathrm{ka}$ and is associated with a broad scale drying (e.g., Newby et al., 2000; Shuman et al., 2001; Shuman and Donnelly, 2006; Oswald et al., 2007; Marsicek et al., 2013). Recent analysis of paleolimnologic data indicates that this drying is associated with cooling of coastal air by $0.5-2.5^{\circ} \mathrm{C}$ and a precipitation decrease of $\sim 100 \mathrm{~mm}$, linked to cooler surface temperatures in the North Atlantic Ocean (Marsicek et al., 2013). Wetter conditions prevailed post $3.8 \mathrm{ka}$ (cf. Shuman and Donnelly, 2006; Oswald et al., 2007; Marsicek et al., 2013) (Figure 9) with an inferred period of heightened hurricane activity ca. 3.6-3.4 ka (Toomey et al., 2013). Cores from the Makepeace Cedar Swamp in far eastern Massachusetts indicate the onset of the wettest conditions post-glacial at ca. $3.2 \mathrm{ka}$ (Newby et al., 2000). The penultimate eolian depositional event is represented by only the Trailhead site with two OSL ages of ca. $2.4 \mathrm{ka}$ (Figure 6). The spatial extent of this eolian depositional event is unknown though these ages may be coincident with a pronounced period of increased hurricane activity in the North Atlantic Ocean (Toomey et al., 2013), but with dry and cool conditions on Cape Cod (Shuman and Donnelly, 2006; Marsicek et al., 2013) (Figure 9). It is salient to note that there is an absence in the presented stratigraphic record of eolian sand deposited ca. $3 \mathrm{ka}$ ago (Figure 9), when inferred hurricane activity was heightened (Toomey et al., 2013).

There is evidence for dune migration at ca. $1.8 \pm 0.2 \mathrm{ka}$ documented at the Butte, Central Valley, Water Tank, and Highway 6 sites (Figures 6-8). In turn, this depositional event is also identified at the Foss Wood site (Figure 6), which exposes the stratigraphy of a tree-covered parabolic dune. This $1.8 \mathrm{ka}$ event 
is associated with migration of parabolic dunes and burial of vegetated surfaces by eolian sand at multiple sites. The inferred paleowind directions from dune forset and avalanche beds are from the west quadrant, possibly with passage of storms to the east and/or winter winds. The $1.8 \mathrm{ka}$ event reflects landscape disturbance at four disparate localities with dune movement and soil burial; which is generally coincident with an episode of increased hurricane activity between ca. 2.0 and $1.6 \mathrm{ka}$ (Toomey et al., 2013) and also a relatively wet period on Cape Cod (Figure 9), with decreasing frequency in forest fires as recorded in Deep Pond (Parshall et al., 2003; Marsicek et al., 2013).

Multiple sites, including Single Paleosol, Trailhead, Central Valley and Butte, show evidence for meters of eolian sand deposition with burial of a paleo-surface at ca. 960 years ago. This event is particularly securely dated with concordant ${ }^{14} \mathrm{C}$ and OSL ages (at one sigma) at the Butte and the Central Valley 2 sites, with eolian sand burying a soil at ca. 950-1000 years ago (Figures 5, 6). Eolian deposition for this event is characterized by dune forset beds at the Butte site, dune avalanche beds at the Single Paleosol site, and sand sheet deposits at the Trailhead and the Central Valley 2 sites. This variety of facies indicates widespread eolian deposition with active dune migration and interdune sand sheet accretion Inferred paleowind directions from two sites are from the northwest reflecting strong winds with possible passage of storms to the east and/or winter winds. The initiation of this eolian depositional event at ca. 1000 year ago is coeval with a well-documented period of enhanced hurricane activity in the North Atlantic (Figure 9), associated with the elevated sea surface temperatures during the Medieval Climate Anomaly (Mann et al., 2009; Toomey et al., 2013). A limnologic record (Deep Pond; Figure 9) from Cape Cod indicates particularly wet conditions from ca. 1200-800 years ago (Marsicek et al., 2013). The apparent continuity of eolian deposition to ca. 700 year ago may reflect succeeding disturbance by storms with a short recurrence interval (decades to century) inhibiting dune stabilization (cf. Houser, 2013) or a significant lag time (centuries) for ecologic succession and stabilization of the landscape (cf. Lichter, 2000).

There is evidence for eolian deposition in the past ca. 500 years (Figure 9). The oldest OSL ages for this event are $530 \pm$ $60,480 \pm 65,425 \pm 70$, and $380 \pm 80$ year ago from the Single Paleosol, Central Valley 1, and Butte sites, respectively. These OSL ages indicate that renewed dune movement commenced ca. 300-500 years ago roughly coincident with initial European settlement. Paleowind directions from the east to northeast for this event are consistent with historic spring and fall threshold winds (Figure 2). A variety of proxy records document a period of increased hurricane reoccurrence in the North Atlantic between ca. 600 and 400 years ago (e.g., Liu and Fearn, 1993; Donnelly et al., 2001; Scileppi and Donnelly, 2007; Toomey et al., 2013) (Figure 9). However, sediment records from lakes on Cape Cod show at least a 5-fold increase in charcoal starting at ca. 300 years ago (Parshall et al., 2003), reflecting forest clearance with European settlement, which has been implicated in dune reactivation on Cape Cod (Forman et al., 2008). Charcoal records from lakes in northern New England show a noticeable spike at ca. 500 years (Clifford and Booth, 2013), which may reflect increased fire frequency, independent of European land use. Thus, the initiation of eolian depositional ca. 500-300 years ago may reflect a combination of factors including heightened storminess, European landscape disturbance and increased fire frequency.

There is also evidence for eolian deposition burying soil surfaces in the past 250 years concomitant with dense historic settlement of Cape Cod (Cogbill et al., 2002; Motzkin et al., 2002; Eberhardt et al., 2003; Forman et al., 2008). The Pilgrims, North American pioneers, arrived on Cape Cod on November 11, 1620 , though they moved to Plymouth within a month, the Cape was an early area of European land use (Kittredge, 1968, p. 20). Timber harvesting soon commenced around Provincetown and prompted the earliest known conservation law in AD 1626 to ensure that the locals had a ready timber supply (Geller, 1974, p. 27). Intensive land use on Cape Cod began ca. AD 1630 with planting of crops and rampant tree felling which resulted in exposed soils for wind erosion (Cronon, 1983; Holmes et al., 1998 , p. 56). Unregulated livestock grazing was common postAD 1630 with cattle and sheep requiring no confined pasturage; swine were also allowed to roam freely and root up soil with feeding (Kittredge, 1968, pp. 71-72). Extensive corn planting during this time depleted soils of nutrients and in AD 1637 one farmer wrote that, "after five or six years, [the soil] grows barren beyond belief" (Cronon, 1983, p. 125). Town fathers by the AD 1670s expressed concern about the limited supply of timber (Kittredge, 1968, p. 86). Blowing sand emerged as a persistent problem to Cape Cod residents in the early AD 1700's with large areas around Provincetown described as "deserts" in AD 17251730 (Rubertone, 1985, pp. 90-92; Holmes et al., 1998, p. 57). A Massachusetts Senate Document from AD 1714 indicates the scale of blowing sand around Provincetown was such that the harbor at Cape Cod was infilling jeopardizing docking of ships (Leatherman, 1979). Active dune migration persisted through the 18th to 21 st centuries as a legacy of past landscape disturbance with initial European settlement (Forman et al., 2008).

\section{CONCLUSION}

Stratigraphic and sedimentologic observations, particularly the burial of Spodosol-like soils and associated ${ }^{14} \mathrm{C}$ and OSL ages, indicate that there were at least six eolian depositional events at ca. $3750,2500,1800,960,430$, and $<250$ years ago. The oldest two events are represented by just one locality and thus the broader environmental significance is unknown. However, the younger four events are identified in three or more sites and reflect dune migration and sand sheet accretion, indicative of pervasive eolian processes. The timing of eolian deposition, particularly the initiation ages, correspond to documented periods of increased hurricane activity in the North Atlantic at 2.0-1.6 and $1.0 \mathrm{ka}$ (cf. Mann et al., 2009; Toomey et al., 2013) and wetter coastal climate (Marsicek et al., 2013). Paleowinds associated with the two youngest events are predominantly from the northwest and west and perhaps reflect winds from the passage of storms to the east and/or winter winds. Eolian systems of Cape Cod appear sensitive to storm/hurricane disturbance despite generally wetter conditions in past $4 \mathrm{ka}$. Dune reactivation was enhanced in the past ca. 400 years and probably reflects multiple processes including anthropogenic landscape disturbance with European 
settlement, heightened period of storminess and higher incidence of forest fires.

\section{ACKNOWLEDGMENTS}

This study was supported by a cooperative agreement (CAH60000030300) with the National Park Service, Cape Cod National Seashore. Assistance in the field by M. Kendall and L. Marin and in the laboratory by J. Pierson and J. Gomez is much appreciated. The remote sensing context for this study was provided ably by M. Sultan, Z. Sagintayev, and R. Beck. S. Smith provided valuable ecological insights, literature sources and assistance with field logistics. The comments of J. Donnelly are much appreciated.

\section{REFERENCES}

Aitken, M. J. (1992). Optical dating. Quat. Sci. Rev. 11, 127-131. doi: 10.1016/02773791(92)90053-B

Barchyn, T. E., and Hugenholtz, C. H. (2012). Winter variability of aeolian sediment transport threshold on a cold-climate dune. Geomorphology 177, 38-50. doi: 10.1016/j.geomorph.2012.07.012

Birkeland, P. (1999). Soils and Geomorphology. New York, NY: Oxford University Press.

Bosse, E. R., Chamberlain, K. E., and Foster, D. R. (2001). Landscape and regional impacts of hurricanes in New England. Ecol. Monogr. 71, 27-48. doi: 10.1890/0012-9615(2001)071[0027:LARIOH]2.0.CO;2

Clarke, M. L., and Rendell, H. M. (2009). The impact of North Atlantic storminess on western European coasts: a review. Quat. Int. 195, 31-41. doi: 10.1016/j.quaint.2008.02.007

Clifford, M. J., and Booth, R. K. (2013). Increased probability of fire during late Holocene droughts in northern New England. Clim. Change 119, 693-704. doi: 10.1007/s10584-013-0771-y

Cogbill, C. V., Burk, J., and Motzkin, G. (2002). The forests of presettlement New England, USA: spatial and compositional patterns based on town proprietor surveys. J. Biogeogr. 29, 1279-1304. doi: 10.1046/j.1365-2699.2002.00757.x

Cook, B. I., Smerdon, J. E., Seager, R., and Cook, E. R. (2014). Pan-continental droughts in North America over the last millennium. J. Clim. 27, 383-397. doi: 10.1175/JCLI-D-13-00100.1

Cronon, W. (1983). Changes in the Land. New York, NY: Hill and Wang.

Dijkmans, J. W. A., and Mucher, H. J. (1989). Niveo-aeolian sedimentation of loess and sand-an experiment and mircomorphological approach. Earth Surf. Proces. Landforms 14, 303-315. doi: 10.1002/esp.3290140406

Disraeli, D. J. (1984). The effect of sand deposits on the growth and morphology of Ammophila breviligulata. J. Ecol. 61, 65-75.

Donnelly, J. P., Bryant, S. S., Butler, J., Dowling, J. J., Fan, L., Hausmann, N., et al. (2001). $700 \mathrm{yr}$ sedimentary record of intense hurricane landfalls in southern New England. Geol. Soc. Am. Bull. 113, 714-727. doi: 10.1130/00167606(2001) 113<0714:YSROIH > 2.0.CO;2

Duller, G. A. T. (2008). Single-grain optical dating of Quaternary sediments: why aliquot size matters in luminescence dating. Boreas 37, 589-612. doi: 10.1111/j.1502-3885.2008.00051.x

Duller, G. A. T., Botter-Jensen, L., and Murray, A. S. (2003). Combining infraredand green-laser stimulation sources in single-grain luminescence measurements of feldspar and quartz. Radiat. Meas. 37, 543-550. doi: 10.1016/S13504487(03)00050-7

Durcan, J. A., and Duller, G. A. T. (2011). The fast ratio: a rapid measure for testing the dominance of the fast component in the initial OSL signal from quartz. Radiat. Meas. 46, 1065-1072. doi: 10.1016/j.radmeas.2011.07.016

Eberhardt, R. W., Foster, D. R., Motzkin, G., and Hall, B. (2003). Conservation of changing landscapes: vegetation and land-use history of Cape Cod National Seashore. Ecol. Appl. 13, 68-84. doi: 10.1890/1051-0761(2003)013[0068:COCLVA]2.0.CO;2

Fain, J., Soumana, S., Montret, M., Miallier, D., Pilleyre, T., and Sanzelle, S. (1999). Luminescence and ESR dating-beta-dose attenuation for various grain shapes calculated by a Monte-Carlo method. Quat. Sci. Rev. 18, 231-234. doi: 10.1016/S0277-3791(98)00056-0
Fairbanks, R. G., Mortlock, R. A., Chiu, T. C., Cao, L., Kaplan, A., Guilderson, T. P., et al. (2005). Radiocarbon calibration curve spanning 0 to 50,000 years BP based on paired Th-230/U-234/U-238 and C-14 dates on pristine corals. Quat. Sci. Rev. 24, 1781-1796. doi: 10.1016/j.quascirev.2005. 04.007

Forman, S. L., Sagintayev, Z., Sultan, M., Smith, S., Becker, R., Kendall, M., et al. (2008). The twentieth-century migration of parabolic dunes and wetland formation at Cape Cod National Sea Shore, Massachusetts, USA: landscape response to a legacy of environmental disturbance. Holocene 18, 765-774. doi: $10.1177 / 0959683608091796$

Foster, D. R. (1988). Species and stand response to catastrophic wind in central New England, USA. J. Ecol. 76, 135-151. doi: 10.2307/2260458

Foster, D. R., and Boose, E. R. (1995). "Hurricane disturbance regimes in temperate and tropical forest ecosystems," in Wind and Trees, eds M. P. Coutts and J. Grace (Cambridge: Cambridge University Press), 305-339.

Foster, D. R., Motzkin, G., O'Keefe, J., Boose, E., Orwig, D., Fuller, J., et al. (2006). "The environmental and human history of New England," in Forests in Time, eds D. Foster and J. D. Aber (New Haven, CT: Yale University Press), 43-101.

Fryberger, S. G., and Dean, G. (1979). "Dune forms and wind regime," in A Study of Global Seas. U.S. Geological Survey Professional Paper 1052, ed E. D. McKee (Washington, DC), 137-169.

Galbraith, R. F., and Green, P. F. (1990). Estimating the component ages in a finite mixture. Nucl. Tracks Radiat. Meas. 17, 197-206. doi: 10.1016/13590189(90)90035-V

Galbraith, R. F., and Roberts, R. G. (2012). Statistical aspects of equivalent dose and error calculation and display in OSL dating: an overview and some recommendations. Quat. Geochronol. 11, 1-27. doi: 10.1016/j.quageo. 2012.04.020

Galbraith, R. F., Roberts, R. G., Laslett, G. M., Yoshida, H., and Olley, J. M. (1999). Optical dating of single and multiple grains of quartz from Jinmium rock shelter, northern Australia, part 1, Experimental design and statistical models. Archaeometry 41, 339-364. doi: 10.1111/j.1475-4754.1999. tb00987.x

Geller, L. D. (1974). Pilgrims in Eden: Conservation Policies at New Plymouth. Wakefield, MA: Pride Publications.

Hansom, J. D., and Hall, A. M. (2009). Magnitude and frequency of extra-tropical North Atlantic cyclones: a chronology from cliff-top storm deposits. Quat. Int. 195, 42-52. doi: 10.1016/j.quaint.2007.11.010

Holmes, R. D., Hertz, C. D., and Mulholland, M. T. (1998). Historic Cultural Land Use Study of Lower Cape Cod: A Study of the Historical Archeology and History Of the Cape Cod National Seashore and the Surrounding Region. Amherst, MA: Archaeological Services, The Environmental Institute, University of Massachusetts, 277.

Houser, C. (2013). A longshore variation in the morphology of coastal dunes: implications for storm response. Geomorphology 199, 48-61. doi: 10.1016/j.geomorph.2012.10.035

Hugenholtz, C. H., and Wolfe, S. A. (2005). Biogeomorphic model of dunefield activation and stabilization on the northern Great Plains. Geomorphology 70 , 53-70. doi: 10.1016/j.geomorph.2005.03.011

Kittredge, H. C. (1968). Cape Cod: Its People and Their History. Boston, MA: Houghton Mifflin Company.

Koster, E. A., and Dijkmans, J. W. A. (1988). Niveo-aeolian deposits and denivation forms, with special reference to the Great Kobuk sand dunes, northwestern Alaska. Earth Surf. Process. Landforms 13, 153-170. doi: 10.1002/esp.3290130206

Leatherman, S. P. (1979). "Environmental geologic guide to Cape Cod National Seashore," in Field Trip Guide Book to the Eastern Section of the Society of Economic Paleontologists and Mineralogists (Amherst, MA: Society of Economic Paleontologists and Mineralogists), 249.

Lichter, J. (2000). Colonization constraints during primary succession on coastal Lake Michigan sand dunes. J. Ecol. 88, 825-839. doi: 10.1046/j.13652745.2000.00503.x

Liu, K.-B. (2004). "Paleotempestology: principles, methods, and examples from Gulf Coast lake sediments," in Hurricanes and Typhoons: Past, Present, and Future, eds R. J. Murnane and K.-B. Liu (New York, NY: Columbia University Press), 13-57.

Liu, K.-B., and Fearn, M. L. (1993). Lake-sediment record of late Holocene hurricane activities from coastal Alabama. Geology 21, 793-796. 
Luna, M., Parteli, E. J. R., Duran, O., and Herrmann, H. J. (2011). Model for the genesis of coastal dune fields with vegetation. Geomorphology 129, 215-224. doi: 10.1016/j.geomorph.2011.01.024

Madsen, A. T., Duller, G. A. T., Donnelly, J. P., Roberts, H. M., and Wintle, A. G. (2009). A chronology of hurricane landfalls at Little Sippewissett Marsh, Massachusetts, USA, using optical dating. Geomorphology 109, 36-45. doi: 10.1016/j.geomorph.2008.08.023

Madsen, A. T., and Murray, A. S. (2009). Optically stimulated luminescence dating of young sediments: a review. Geomorphology 109, 3-16. doi: 10.1016/j.geomorph.2008.08.020

Mangan, J. M., Overpeck, J. T., Webb, R. S., Wessman, C., and Goetz, A. F. H. (2004). Response of Nebraska Sand Hills natural vegetation to drought, fire, grazing, and plant functional type shifts as simulated by the century model. Clim. Change 63, 49-90. doi: 10.1023/B:CLIM.0000018516. 53419.90

Mann, M. E., Woodruff, J. D., Donnelly, J. P., and Zhang, Z. (2009). Atlantic hurricanes and climate over the past 1,500 years. Nature 460, 880-883. doi: 10.1038 /nature08219

Marsicek, J. P., Shuman, B., Brewer, S., Foster, D. R., and Oswald, W. W. (2013). Moisture and temperature changes associated with the mid-Holocene Tsuga decline in the northeastern United States. Quat. Sci. Rev. 80, 129-142. doi: 10.1016/j.quascirev.2013.09.001

Maun, M. A. (1998). Adaptations of plants to burial in coastal sand dunes. Can. J. Bot. 76, 713-738. doi: 10.1139/b98-058

Maun, M. A., and Lapierre, J. (1984). The effects of burial by sand on Ammophila breviligulata. J. Ecol. 72, 827-839.

Maun, M. A., and Perumal, J. (1999). Zonation of vegetation on lacustrine coastal dunes: effects of burial by sand. Ecol. Lett. 2, 14-18. doi: 10.1046/j.14610248.1999.21048.x

McCaffrey, C., and Leatherman, S. P. (1979). "Historical land use practices and dune instability in the Province Lands," in Environmental Geologic Guide to Cape Cod National Seashore, ed S. P. Leatherman (Amherst, MA: Field Trip Guide Book for the Eastern Section of the Society of Economic Paleontologists and Mineralogists), 249

Meier, H. A., Nordt, L. C., Forman, S. L., and Driese, S. G. (2013). Late Quaternary alluvial history of the middle Owl Creek drainage basin in central Texas: a record of geomorphic response to environmental change. Quat. Int. 306, 24-41. doi: 10.1016/j.quaint.2013.07.010

Mejdahl, V., and Christiansen, H. H. (1994). Procedures used for luminescence dating of sediments. Quat. Sci. Rev. 13, 403-406. doi: 10.1016/02773791(94)90049-3

Motzkin, G., Eberhardt, R., Hall, B., Foster, D. R., Harrod, J., and MacDonald, D. (2002). Vegetation variation across Cape Cod, Massachusetts: environmental and historical determinants. J. Biogeogr. 29, 1439-1454. doi: 10.1046/j.13652699.2002.00800.x

Motzkin, G., Wilson, P., Foster, D. R., and Allen, A. (1999). Vegetation patterns in heterogeneous landscapes: the importance of history and environment. J. Vegetation Sci. 10, 903-920. doi: 10.2307/3237315

Murray, A. S., and Wintle, A. G. (2003). The single aliquot regenerative dose protocol: potential for improvements in reliability. Radiat. Meas. 37, 377-381. doi: 10.1016/S1350-4487(03)00053-2

Newby, P. E., Killoran, P., Waldorf, M. R., Shuman, B. N., Webb, R. S., and Webb, T. (2000). 14,000 years of sediment, vegetation, and water-level changes at the Makepeace Cedar Swamp, southeastern Massachusetts. Quat. Res. 53, 352-368. doi: 10.1006/qres.1999.2120

NOAA. (2002). Climatography of the United States NO. 81, Monthy Normals of Temperature, Precipitation and Heating and Cooling Days, 19712000, Massachusetts. Asheville, NC: National Oceanic and Atmospheric Administration, National Climatic Data Center, 16

Ockay, C., and Hubert, J. F. (1996). Mineralogy and provenance of Pleistocene outwash-plain and modern beach sands of outer Cape Cod, Massachusetts, USA. Mar. Geol. 130, 127-137.

Ollerhead, J. R., Davidson-Arnott, I., Walker, J., and Mathew, S. (2013). Annual to decadal morphodynamics of the foredune system at Greenwich Dunes, Prince Edward Island, Canada. Earth Surf. Process. Landforms 38, 284-298. doi: 10.1002/esp.3327

Olley, J., Caitcheon, G., and Murray, A. S. (1998). The distribution of apparent dose as determined by optically stimulated luminescence in small aliquots of fluvial quartz: implications for dating young sediments. Quat. Sci. Rev. 17, 1033-1040. doi: 10.1016/S0277-3791(97)00090-5

Oswald, W. W., Faison, E. K., Foster, D. R., Doughty, E. D., Hall, B. R., and Hansen, B. C. S. (2007). Post-glacial changes in spatial patterns of vegetation across southern New England. J. Biogeogr. 34, 900-913. doi: 10.1111/j.13652699.2006.01650.x

Parshall, T., Foster, D. R., Faison, E., MacDonald, D., and Hansen, B. C. S. (2003). Long-term history of vegetation and fire in pitch pine-oak forests on Cape Cod, Massachusetts. Ecology 84, 736-748. doi: 10.1890/00129658(2003)084[0736:LTHOVA]2.0.CO;2

Peterson, C. J., Carson, W. P., McCarthy, B. C., and Picket, S. T. A. (1990). Microsite variation and soil dynamics within newly created treefall pits and mounds. Okios 58, 39-46.

Prescott, J. R., and Hutton, J. T. (1994). Cosmic-ray contributions to dose-rates for luminescence and ESR dating-large depths and long-term variations. Radiat. Meas. 23, 497-500. doi: 10.1016/1350-4487(94)90086-8

Pye, K., and Tsoar, H. (1990). Aeolian Sand and Sand Dunes. Boston, MA: Unwin Hyman.

Rubertone, P. E. (1985). "Changes in the coastal wilderness: historical land use patterns on outer Cape Cod, 17th-19th centuries," in Chapters in the Archeology of Cape Cod, III: The Historic Period and Historic Period Archeology, ed F. P. McManamom (Boston, MA: Division of Cultural Resources, North Atlantic Regional Office, National Park Service, U.S. Department of Interior), 17-117.

Ruhe, R. V., and Olson C. G. (1980). Soil Welding. Soil Sci. 130, 132-139. doi: 10.1097/00010694-198009000-00004

Ruz, M. H., and Allard, M. (1995). Sedimentary structures of cold-climate coastal dunes, eastern Hudson-Bay, Canada. Sedimentology 42, 725-734. doi: 10.1111/j.1365-3091.1995.tb00405.x

Sala, O. E., Parton, W. J., Joyce, L. A., and Lauenroth, W. K. (1988). Primary production of the central grassland region of the United States. Ecology 69, 40-45. doi: $10.2307 / 1943158$

Scileppi, E., and Donnelly, J. P. (2007). Sedimentary evidence of hurricane strikes in western Long Island, New York. Geochem. Geophys. Geosyst. 8. doi: 10.1029/2006GC001463

Shuman, B., Bravo, J., Kaye, J., Lynch, J. A., Newby, P., and Webb, T. (2001). Late Quaternary water-level variations and vegetation history at Crooked Pond, southeastern Massachusetts. Quat. Res. 56, 401-410. doi: 10.1006/qres.2001.2273

Shuman, B., and Donnelly, J. P. (2006). The influence of seasonal precipitation and temperature regimes on lake levels in the northeastern United States during the Holocene. Quat. Res. 65, 44-56. doi: 10.1016/j.yqres.2005.09.001

Stilgoe, J. R. (1981). A New England coastal wilderness. Geogr. Rev. 71, 33-50. doi: $10.2307 / 214550$

Thoreau, H. D. (2004). Cape Cod. Princeton, NJ: Princeton University Press.

Toomey, M. R., Curry, W. B., Donnelly, J. P., and van Hengstum, P. J. (2013). Reconstructing 7000 years of North Atlantic hurricane variability using deepsea sediment cores from the western Great Bahama Bank. Paleoceanography 28. doi: $10.1002 /$ palo. 20012

Tripaldi, A., and Forman, S. L. (2007). Geomorphology and chronology of Late Quaternary dune fields of western Argentina. Palaeogeogr. Palaeoclimatol. Palaeoecol. 251, 300-320. doi: 10.1016/j.palaeo.2007. 04.007

Vandijk, D., and Law, J. (1995). Sublimation and aeolian sand movement from a frozen surface-Experimental results from Presquille-Beach, Ontario. Geomorphology 11, 177-187. doi: 10.1016/0169-555X(94) 00065-Y

Williams, H. F. L. (2013). 600-year sedimentary archive of hurricane strikes in a prograding beach ridge plain, southwestern Louisiana. Mar. Geol. 336, 170-183. doi: 10.1016/j.margeo.2012.12.005

Wintle, A. G., and Murray, A. S. (2006). A review of quartz optically stimulated luminescence characteristics and their relevance in singlealiquot regeneration dating protocols. Radiat. Meas. 41, 369-391. doi: 10.1016/j.radmeas.2005.11.001

Wright, D. K., Forman, S. L., Waters, M. R., and Ravesloot, J. C. (2011). Holocene eolian activation as a proxy for broad-scale landscape change on the Gila River Indian Community, Arizona. Quat. Res. 76, 10-21. doi: 10.1016/j.yqres.2011.04.008 
Zeng, H., Chambers, J. Q., Negron-Juarez, R. I., Hurtt, G. C., Baker, D. B., and Powell, M. D. (2009). Impacts of tropical cyclones on US forest tree mortality and carbon flux from 1851 to 2000. Proc. Natl. Acad. Sci. U.S.A. 106, 7888-7892. doi: 10.1073/pnas.0808 914106

Conflict of Interest Statement: The author declares that the research was conducted in the absence of any commercial or financial relationships that could be construed as a potential conflict of interest.

Received: 28 November 2014; paper pending published: 22 December 2014; accepted: 22 January 2015; published online: 17 February 2015.
Citation: Forman SL (2015) Episodic eolian sand deposition in the past 4000 years in Cape Cod National Seashore, Massachusetts, USA in response to possible hurricane/storm and anthropogenic disturbances. Front. Earth Sci. 3:3. doi: 10.3389/feart. 2015.00003

This article was submitted to Quaternary Science, Geomorphology and Paleoenvironment, a section of the journal Frontiers in Earth Science.

Copyright (C) 2015 Forman. This is an open-access article distributed under the terms of the Creative Commons Attribution License (CC BY). The use, distribution or reproduction in other forums is permitted, provided the original author(s) or licensor are credited and that the original publication in this journal is cited, in accordance with accepted academic practice. No use, distribution or reproduction is permitted which does not comply with these terms. 